\title{
Hygroscopicity and composition of Alaskan Arctic CCN during April 2008
}

\author{
R. H. Moore ${ }^{1}$, R. Bahreini ${ }^{2,3}$, C. A. Brock ${ }^{2}$, K. D. Froyd ${ }^{2,3}$, J. Cozic $^{2,3, *}$, J. S. Holloway ${ }^{2,3}$, A. M. Middlebrook ${ }^{2}$, \\ D. M. Murphy ${ }^{2}$, and A. Nenes ${ }^{1,4}$ \\ ${ }^{1}$ School of Chemical \& Biomolecular Engineering, Georgia Institute of Technology, Atlanta, Georgia, USA \\ ${ }^{2}$ Earth Systems Research Laboratory, National Oceanic and Atmospheric Administration, Boulder, Colorado, USA \\ ${ }^{3}$ Cooperative Institute for Research in Environmental Sciences, University of Colorado, Boulder, Colorado, USA \\ ${ }^{4}$ School of Earth \& Atmospheric Sciences, Georgia Institute of Technology, Atlanta, Georgia, USA \\ *now at: Laboratoire de Glaciologie et Géophysique de l'Environnement, Grenoble, France
}

Received: 14 May 2011 - Published in Atmos. Chem. Phys. Discuss.: 3 August 2011

Revised: 8 November 2011 - Accepted: 14 November 2011 - Published: 29 November 2011

Abstract. We present a comprehensive characterization of cloud condensation nuclei (CCN) sampled in the Alaskan Arctic during the 2008 Aerosol, Radiation, and Cloud Processes affecting Arctic Climate (ARCPAC) project, a component of the POLARCAT and International Polar Year (IPY) initiatives. Four distinct air mass types were sampled including a cleaner Arctic background and a relatively pristine sea ice boundary layer as well as biomass burning and anthropogenic pollution plumes. Despite differences in chemical composition, inferred aerosol hygroscopicities were fairly invariant and ranged from $\kappa=0.1-0.3$ over the atmospherically-relevant range of water vapor supersaturations studied. Organic aerosols sampled were found to be well-oxygenated, consistent with long-range transport and aerosol aging processes. However, inferred hygroscopicities are less than would be predicted based on previous parameterizations of biogenic oxygenated organic aerosol, suggesting an upper limit on organic aerosol hygroscopicity above which $\kappa$ is less sensitive to the $\mathrm{O}: \mathrm{C}$ ratio. Most Arctic aerosols act as $\mathrm{CCN}$ above $0.1 \%$ supersaturation, although the data suggest the presence of an externally-mixed, non$\mathrm{CCN}$-active mode comprising approximately $0-20 \%$ of the aerosol number. $\mathrm{CCN}$ closure was assessed using measured size distributions, bulk chemical composition, and assumed aerosol mixing states; $\mathrm{CCN}$ predictions tended toward overprediction, with the best agreement $( \pm 0-20 \%)$ obtained by assuming the aerosol to be externally-mixed with soluble organics. Closure also varied with $\mathrm{CCN}$ concentration, and

Correspondence to: A. Nenes

(athanasios.nenes@gatech.edu) the best agreement was found for $\mathrm{CCN}$ concentrations above $100 \mathrm{~cm}^{-3}$ with a 1.5 - to 3 -fold overprediction at lower concentrations.

\section{Introduction}

The Arctic is particularly sensitive to climatic changes because of the complex feedbacks between surface temperature and surface albedo, among other factors. Trace gas and aerosol species have the potential to modify this feedback through their interaction with shortwave and longwave radiation, and are thus, an important area of active research. A number of long-term measurements around the Arctic have indicated that these species vary seasonally, and their concentrations peak during late winter and early spring when mid-latitude anthropogenic pollution is transported northward and injected into the vertically-stratified springtime Arctic atmosphere (Quinn et al., 2007; Shaw, 1995).

Termed "Arctic haze", these pollution layers can persist for days or weeks and have been attributed mostly to anthropogenic sources in northern Europe and Asia (Law and Stohl, 2007). Recent work indicates that biomass burning emissions may contribute more to the haze layers than previously thought (Warneke et al., 2010; Quinn et al., 2008; Stohl et al., 2006, 2007), possibly because industrial emissions contributing to the haze have steadily decreased over past decades (Quinn et al., 2007), or because of improved instrumental capabilities for detecting and attributing the biomass burning contribution. 
Aerosol species can impact the Arctic energy balance directly by absorbing and scattering sunlight, and also indirectly, through their ability to act as cloud condensation nuclei $(\mathrm{CCN})$ and modify cloud properties. It is known that increased CCN loadings produce more numerous and smaller cloud droplets, which reflect more incoming shortwave, solar radiation back into space, thereby cooling the Earth's surface (Twomey, 1977a). However, it has been suggested by a number of studies that this cooling effect is more than offset in the Arctic by changes in longwave cloud emissivity (Alterskjær et al., 2010; Garrett and Zhao, 2006; Lubin and Vogelmann, 2006; Shupe and Interieri, 2004; Garrett et al., 2002). This is because of decreased solar insolation during the Arctic winter-spring and because low-level Arctic clouds tend to be diffuse and optically thin. Additionally, the high albedo of surface snow and ice limits the potential cooling associated with light scattering from these clouds. Smaller cloud droplets also inhibit ice crystal riming and droplet collision-coalescence processes, which increase the cloud lifetime against precipitation (Lance et al., 2011; Mauritsen et al., 2011; Borys et al., 2000, 2003; Albrecht, 1989). Thus, accurate in-situ observations of aerosol and cloud properties are essential for models to account for these "indirect effects" of aerosols on Arctic clouds and climate.

In past decades, measurements of $\mathrm{CCN}$ have been made on a variety of ground-based and airborne platforms throughout the Arctic by exposing particles to a specified water vapor supersaturation and counting the number of droplets that are formed. Hoppel et al. (1973) used a thermal-gradient diffusion cloud chamber to measure vertical profiles of $\mathrm{CCN}$ above the Yukon Valley, approximately 100 miles north of Fairbanks, Alaska, during February. A distinct vertical gradient was observed and $\mathrm{CCN}$ concentrations were found to increase by about a factor of three above $2 \mathrm{~km}$ altitude (from $\sim 100 \mathrm{CCN} \mathrm{cm}^{-3}$ near the surface) and exhibited increased sensitivity to supersaturation.

Shaw (1986) performed CCN measurements of episodic Arctic haze in central Alaska during January-February, also using a thermal diffusion chamber, and found that particles behaved like soluble salts, with approximately 10 $30 \mathrm{CCN} \mathrm{cm}^{-3}$ measured at $\sim 0.3-0.5 \%$ supersaturation.

Hegg et al. (1995) studied CCN during seven research flights in April, 1992, which were conducted $350 \mathrm{~km}$ north of Alaska during the Arctic Leads Experiment (LEADEX). $\mathrm{CCN}$ concentrations were generally less than $100 \mathrm{~cm}^{-3}$ with a mean of $47 \pm 19 \mathrm{~cm}^{-3}$, while the Aitken mode particle concentration varied from 135 to $4600 \mathrm{~cm}^{-3}$. Most aerosols did not act as $\mathrm{CCN}$ even at $1 \%$ supersaturation (the mean $\mathrm{CCN}$-active fraction was $0.15 \pm 0.08$ ). This unexpectedlylow $\mathrm{CCN}$-active fraction was attributed to the prevalence of smaller, Aitken mode particles. Concurrent $\mathrm{SO}_{4}^{2-}$ measurements did not correlate with $\mathrm{CCN}$ concentrations at $0.3 \%$ supersaturation $(r=0.046)$, but improved at $1 \%$ supersaturation $(r=0.640)$, suggesting that the sulfate was present in the smaller particles.
Hegg et al. (1996) made measurements of aerosol size, volatility, and CCN activity near Prudhoe Bay, Alaska, during June 1995. At $1 \%$ supersaturation, they found mean CCN concentrations of 0 to $178 \mathrm{~cm}^{-3}$, corresponding to $\mathrm{CCN}$-active fractions of around 0.10 , similar to those of Hegg et al. (1995). The CCN-active fraction was found to correlate weakly with the aerosol mass fraction volatile at $320^{\circ} \mathrm{C}$ (e.g., sulfate and organic species), suggesting that compositional effects were important in modulating CCN concentrations (Hegg et al., 1996).

Bigg and Leck (2001) measured CCN from an icebreaker in the central Arctic Ocean during July to September using a CCN-remover-type instrument (Ji et al., 1998), and found $\mathrm{CCN}$ concentrations of $1-1000 \mathrm{~cm}^{-3}$ at $0.25 \%$ supersaturation, with median daily concentrations of $15-50 \mathrm{~cm}^{-3}$. The highest concentrations were observed over open water and were reduced to less than $200 \mathrm{~cm}^{-3}$ after $24 \mathrm{~h}$ transport over the ice pack. Assuming that all particles were composed of ammonium sulfate generally overpredicted $\mathrm{CCN}$ concentrations by $30 \%$, which is consistent with the $30 \%$ overprediction bias observed by Zhou et al. (2001) and Leck et al. (2002) using hygroscopic growth and CCN measurements during the same cruise. Single-particle electron microscopy indicated that the majority of particles were internally-mixed, but also showed the presence of organic species or other nonhygroscopic, non-volatile aerosol inclusions that likely led to the overprediction bias. Leck et al. (2002) found that CCN were underpredicted by approximately $30 \%$ during clear sky conditions and high wind speeds, which they attributed to the presence of organic surfactants that made the particles more $\mathrm{CCN}$-active than would be expected from the contribution of the inorganic species alone (Leck et al., 2002; Lohmann and Leck, 2005)

Yum and Hudson (2001) measured the vertical distribution of $\mathrm{CCN}$ concentrations (0.04- $0.8 \%$ superaturation) approximately $500 \mathrm{~km}$ north of the Alaskan coast as part of the Arctic Clouds Experiment (ACE) and Surface Heat Budget of the Arctic Ocean (SHEBA) projects in May, 1998. They found that both $\mathrm{CCN}$ and total particle concentrations increased with altitude, on average, from less than $100 \mathrm{~cm}^{-3}$ in the boundary layer to $150-200 \mathrm{~cm}^{-3}$ aloft. Average CCN concentrations at all altitudes increased from roughly $10 \mathrm{~cm}^{-3}$ at $0.02 \%$ supersaturation to $100 \mathrm{~cm}^{-3}$ at $0.1 \%$ supersaturation and $200-300 \mathrm{~cm}^{-3}$ at $0.8 \%$ supersaturation, and the authors attributed the relatively high $\mathrm{CCN}$-active fraction of 0.63 and the slope of the $\mathrm{CCN}$-supersaturation spectrum as indicative of an aged aerosol with few small particles (Yum and Hudson, 2001), and whose variability was likely due to cloud scavenging of higher-altitude aerosol layers that then descended into the boundary layer (Wylie and Hudson, 2002). This is in contrast to the prevalent small particles and low CCN activation ratios observed by Hegg et al. (1995).

More recently, Kammermann et al. (2010) measured summertime $\mathrm{CCN}$ and aerosol hygroscopic growth during the Abisco campaign at the Stordalen mire, Sweden, and saw 

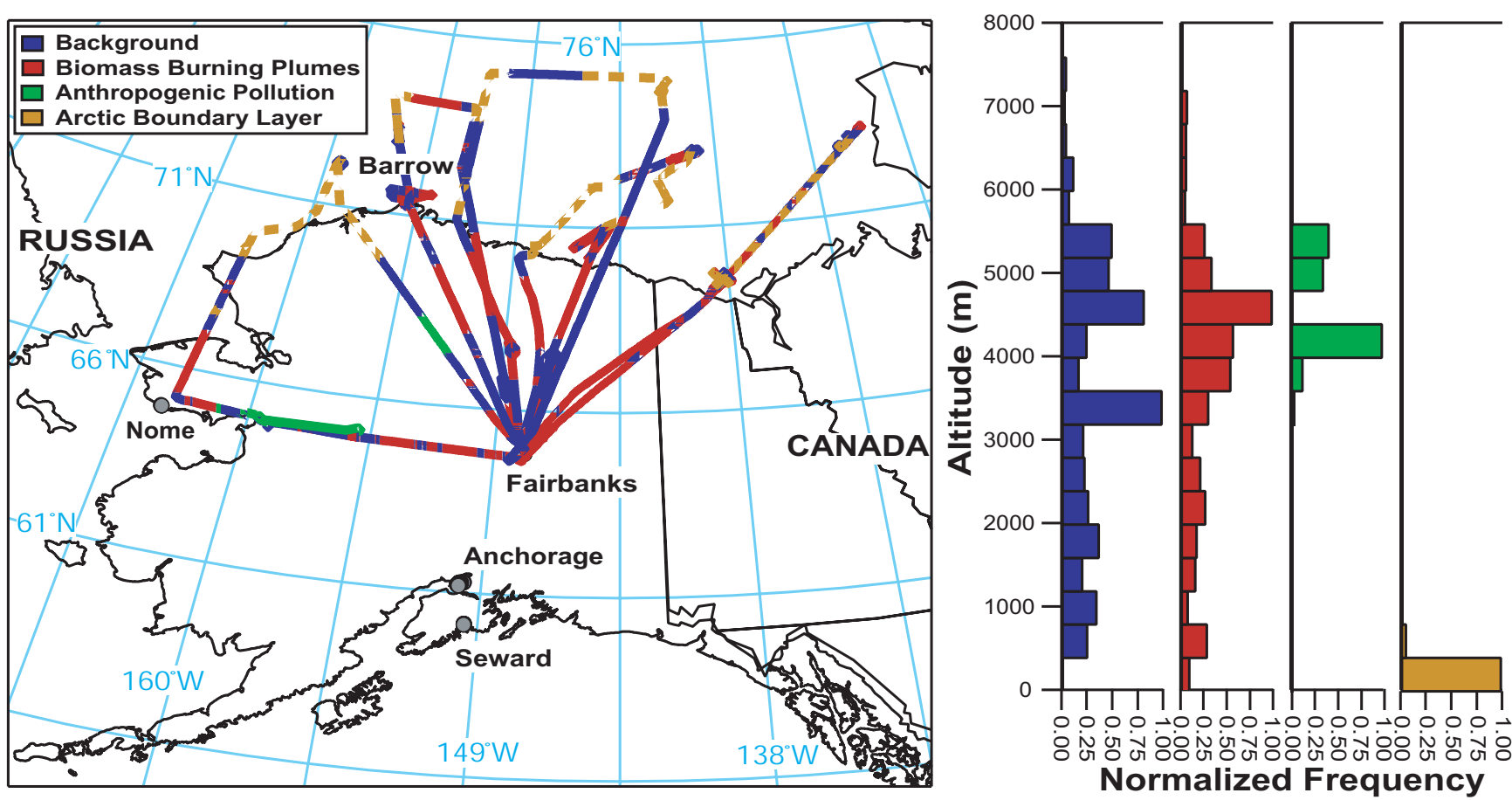

Fig. 1. (Left) Aircraft trajectories for the research flights on April 12th, 15th, 18th, 19th, and 21st, colored by air mass type. Due to vertical profiling, some air mass types overlap. (Right) Vertical profiles showing the altitudes at which each air mass type (background, biomass burning plumes, anthropogenic plumes, Arctic boundary layer) was frequently encountered.

CCN concentrations ranging from $30-700 \mathrm{~cm}^{-3}$ with mean $\mathrm{CCN}$-active fractions of $7-27 \%$ at $0.1-0.7 \%$ supersaturation. Inferred values of the hygroscopicity parameter, $\kappa$ (Petters and Kreidenweis, 2007), obtained from the CCN measurements, were found to range from 0.07 at the highest supersaturation to 0.21 at the lowest supersaturation. $\mathrm{CCN}$ concentration closure was assessed by using $\kappa$ values obtained from the hygroscopic growth measurements to predict $\mathrm{CCN}$, and agreement was typically achieved to within $\pm 11 \%$.

In summary, measurements of Arctic CCN over the past decades have found concentrations to be highly variable, in part due to seasonal changes, but typically on the order of a few tens to hundreds of $\mathrm{CCN} \mathrm{cm}{ }^{-3}$, which constitutes only $7-63 \%$ of total particles present even at supersaturations as high as $0.7-1 \%$. Both $\mathrm{CCN}$ and total particle concentrations have been observed to increase with altitude, underscoring the need for additional airborne studies to complement surface measurements. Additionally, the aerosol mixing state remains poorly characterized with some limited evidence for size-variant aerosol chemistry and the presence of a small non-hygroscopic aerosol mode.

In this paper, we present observations of the $\mathrm{CCN}$ activity and hygroscopic properties of Arctic aerosol sampled during spring 2008 and quantify the uncertainty in CCN predictions based on simplified models of aerosol mixing state and chemical composition relevant for global climate models. We also examine the relationship between aerosol hygroscopicity and oxidation state. It has been suggested that more-oxidized organic aerosol are more hygroscopic (Jimenez et al., 2009), and we explore this relationship in the context of well-aged, Arctic air masses.

\section{Observational data set}

\subsection{Study Location}

An extensive description of the ARCPAC mission and aerosol instrumentation is given by Brock et al. (2011), so only a brief summary is included here. Measurements were made aboard the National Oceanic and Atmospheric Administration WP-3D aircraft based out of Fairbanks, AK $\left(64^{\circ} 48^{\prime} 54^{\prime \prime} \mathrm{N}, 147^{\circ} 51^{\prime} 23^{\prime \prime} \mathrm{W}\right)$. A total of eight research flights were conducted from 3-23 April 2008, including two transit flights into and out of Alaska. We restrict our analysis here to five of the research flights conducted entirely within the Alaskan Arctic (12, 15, 18, 19, and 21 April). As described by Brock et al. (2011), these flights extended from western Alaska near Nome, northeast to the Beaufort Sea, and intercepted four distinct types of air masses (background, biomass burning plumes, anthropogenic pollution plumes, and the Arctic sea ice boundary layer), which will be discussed in detail in Sect. 3.1. A map of the flight tracks is shown in Fig. 1. 


\subsection{Chemical composition measurements}

Mass loadings of non-refractory, sub-micron aerosol species were obtained from a compact time-of-flight aerosol mass spectrometer (C-ToF-AMS) with a pressure-controlled inlet (Bahreini et al., 2008; DeCarlo et al., 2006; Drewnick et al., 2005). The C-ToF-AMS focuses the sample aerosol stream into a narrow beam, which is impacted on a hot plate. Particles are vaporized and ionized before being detected with a compact time of flight mass spectrometer. The instrument was operated in either "particle time of flight" mode or in "mass spectrum" mode. In the former mode, the narrow particle beam is periodically interrupted by a rotating chopper, and the particle time-of-flight across the vacuum chamber is detected and related to size. Size-resolved mass distributions were averaged to five-minute intervals to improve signal-tonoise. In the latter mode, the chopper alternates between completely opening and completely blocking the beam line so that the difference mass spectrum is obtained at $0.2 \mathrm{~Hz}$ with good signal-to-noise, but for the entire particle size distribution. Phase dependent efficiencies were applied to all species measured by the C-ToF-AMS as described in Middlebrook et al. (2012). Mass loadings for sulfate, nitrate, ammonium, and organic aerosol constituents were then calculated from the mass spectra following the procedure of Allan et al. (2003), with relative uncertainties of $\pm 34-38 \%$ (Bahreini et al., 2009).

Aerosol volume fractions were calculated from the C-ToFAMS mass loadings, assuming internally-mixed aerosol, tabulated inorganic species densities, and an organic density of $1400 \mathrm{~kg} \mathrm{~m}^{-3}$ (King et al., 2007). Partitioning of the inorganic aerosol fraction between neutral and acidic sulfate species for each air mass was calculated using the molar ratio of ammonium ions to sulfate and nitrate ions, $R_{\mathrm{SO}_{4}}$, and mass balance as per Nenes et al. (1998). Nitrate constitutes a small fraction of aerosol volume in all air mass types and is assumed to be completely neutralized. For $R_{\mathrm{SO}_{4}}>2$, the sulfate is present as ammonium sulfate, while for $1<R_{\mathrm{SO}_{4}}<2$, the sulfate is present as a mixture of ammonium sulfate and ammonium bisulfate. Finally, for $R_{\mathrm{SO}_{4}}<1$, the sulfate is present as a mixture of ammonium bisulfate and sulfuric acid.

The C-ToF-AMS provides information about the mass fraction of non-refractory chemical constituents, but does not provide any information about the refractory aerosol components (e.g., sea salt, mineral dust, elemental carbon) or mixing state. Such information is obtained using a particle analysis by laser mass spectrometry (PALMS) instrument (Murphy et al., 2006; Thomson et al., 2000). The PALMS instrument ablates and ionizes single particles $(0.15-0.75 \mu \mathrm{m}$ diameters) using a laser, and analyzes the resulting ions with a reflectron time-of-flight mass spectrometer. The positive- or negative-ion mass spectral patterns of each particle are then used to classify the particle as one of six different compositional types according to the dominant constituent in each particle. The compositional types are biomass/biofuel, sul- fate/organic, sea salt, mineral dust, elemental carbon, and unclassified. The unclassified compositional type refers to particles that could not be identified by the automated data processor, although subsequent inspection of these spectra showed them to be consistent with the distribution of other particle types. In addition, particles composed primarily of elemental carbon were found to constitute less than $1 \%$ of particle number. Consequently, we neglect the unclassified and elemental carbon particle type categories in this analysis. Particle number concentrations of each type were computed with a 60 -s resolution and an estimated relative uncertainty of $15 \%$.

\subsection{Particle size distribution measurements}

Dry particle size distribution measurements $(0.003$ to $8.3 \mu \mathrm{m}$ diameters) were obtained at $1 \mathrm{~Hz}$ from a white-light optical particle counter (WLOPC), an ultra-high sensitivity aerosol size spectrometer (UHSAS), and a nucleation mode aerosol size spectrometer (NMASS). An impactor with $1 \mu \mathrm{m}$ cutoff diameter was located upstream of the UHSAS. The NMASS consists of five condensation particle counters, with 0.004, $0.008,0.015,0.030$, and $0.055 \mu \mathrm{m}$ cutoff diameters. Fine particle size distributions ( 0.003 to $1 \mu \mathrm{m}$ diameters) were then calculated by coupling these five size bins to the UHSAS distribution using a nonlinear inversion algorithm (Brock et al., 2000). The calibrated uncertainty of the fine particle concentrations is approximately $\pm 20 \%$, although an additional bias of 5-10\% was noted during aircraft ascent and descent (Brock et al., 2011).

\section{$2.4 \mathrm{CCN}$ measurements}

CCN measurements were made using a Droplet Measurement Technologies (DMT) streamwise thermal-gradient cloud condensation nuclei counter (CCNC, Lance et al., 2006; Roberts and Nenes, 2005), which was located downstream of the 1- $\mu$ m-cutoff-diameter impactor. The CCNC consists of a cylindrical flow tube with wetted walls, on which a linear streamwise temperature gradient is applied. Owing to the greater mass diffusivity of water vapor than the thermal diffusivity of air, a supersaturation is generated with a maximum at the centerline of the flow tube. The supersaturation depends on the applied temperature gradient, flow rate, pressure, and, to a lesser extent, the temperature at the instrument inlet (Roberts and Nenes, 2005). During ARCPAC, the instrument was operated at a constant flow rate $\left(0.75 \mathrm{~L} \mathrm{~min}^{-1}\right)$ and pressure $(450 \mathrm{hPa})$. A flow orifice and active control system were used to ensure that the pressure remained constant, despite changes in ambient pressure with altitude. In the rare instances when the ambient pressure decreased below $450 \mathrm{hPa}$, the instrument pressure varied freely with the ambient pressure. All CCN and total particle concentration measurements during ARCPAC are reported here 
at standard temperature and pressure (STP, $1013 \mathrm{hPa}$ and $273.15 \mathrm{~K})$.

During the research flights, the $\mathrm{CCNC}$ instrument supersaturation was varied between $0.1 \%$ and $0.6 \%$ in a stepwise manner by changing the streamwise temperature gradient, $\Delta T$. Supersaturation, $s$, scales linearly with $\Delta T$ (at constant flow rate and pressure), and this relationship was determined using ammonium sulfate calibration aerosol and Scanning Mobility CCN Analysis (SMCA, Moore et al., 2010). This technique couples the CCNC to an aerosol generation system and scanning mobility particle sizer (SMPS). Ammonium sulfate aerosol are size-classified by the SMPS before being introduced into the $\mathrm{CCNC}$, and particles above a critical dry diameter, $D_{\mathrm{p}, \mathrm{c}}$, act as $\mathrm{CCN}$ and are detected by the CCNC. Köhler theory (Köhler, 1936), is then used to determine $s$ from the measured $D_{\mathrm{p}, \mathrm{c}}$ for each $\Delta T$ following the procedure of Rose et al. (2008) and Moore et al. (2010). Parameters for computing the osmotic coefficient using the ioninteraction approach of Pitzer and Mayorga (1973) were obtained from Clegg and Brimblecombe (1988). The secondary activation peak associated with doubly-charged particles was removed. The effect of the of the DMA transfer function and particle non-sphericity were not considered; however, the error associated with these assumptions is less than $3 \%$, relative (Rose et al., 2008), which is less than the variability of $s$ from the calibrations throughout the field measurements $( \pm 0.04 \%$, absolute). The instrument operating temperature was operated well above the ambient temperatures encountered during ARCPAC, which may cause some particles to partially volatilize prior to activation (Asa-Awuku et al., 2009); however, insufficient information was available to deduce this effect. The total uncertainty in the reported $\mathrm{CCN}$ number concentration derived from counting statistics and small variations in temperature, pressure, and flow rate is $7-16 \%$ for CCN concentrations above $100 \mathrm{~cm}^{-3}$ STP, which were typical.

\section{Results and discussion}

\subsection{Air masses sampled}

During five research flights from 12-21 April, the WP-3D aircraft sampled aerosol from four distinct air mass types (Brock et al., 2011), characterized as:

1. Background: Air masses where both carbon monoxide and acetonitrile mixing ratios were less than $170 \mathrm{ppbv}$ and $100 \mathrm{pptv}$, respectively, and that did not contain layers with large enhancements in aerosol and trace gas concentrations. Observations are consistent with the mean springtime "Arctic haze" values reported from long-term surface observations (Brock et al., 2011). Organics constitute $51 \%$ of the non-refractory aerosol volume, on average, with the remaining volume divided between ammonium nitrate, ammonium sulfate, ammonium bisulfate, and sulfuric acid by an average ratio of approximately $0: 2.5: 4: 3.5$, respectively.

2. Biomass Burning Plumes: Air masses where both carbon monoxide and acetonitrile mixing ratios were greater than $170 \mathrm{ppbv}$ and $100 \mathrm{pptv}$, respectively. Often layers with enhanced aerosol and trace gas concentrations were present. Organics constitute $70 \%$ of the nonrefractory aerosol volume, on average, with the remaining volume divided between ammonium nitrate, ammonium sulfate, ammonium bisulfate, and sulfuric acid by an average ratio of approximately 1:4:4:1, respectively.

3. Anthropogenic Pollution: Air masses where the carbon monoxide mixing ratio exceeded $170 \mathrm{ppbv}$, but where the acetonitrile mixing ratio was less than $100 \mathrm{pptv}$. This case was only observed on 15 April for a short period of time. Organics constitute $40 \%$ of the non-refractory aerosol volume, on average, with the remaining volume divided between ammonium nitrate, ammonium sulfate, ammoninum bisulfate, and sulfuric acid by an average ratio of approximately $0: 1.5: 7: 1.5$, respectively.

4. Arctic Boundary Layer: Air masses over sea ice and below the inversion layer, where ozone mixing ratios were less than $20 \mathrm{ppbv}$ and/or photochemically-active bromine was enhanced, indicating sea-ice surface interaction. Organics constitute $25 \%$ of the non-refractory aerosol volume, on average, with the remaining volume divided between ammonium nitrate, ammonium sulfate, ammoninum bisulfate, and sulfuric acid by an average ratio of approximately 0:1.2:6.4:2.3, respectively.

A detailed description of additional aerosol properties as well as the source and transport characteristics for each air mass type is given by Brock et al. (2011). The ion balance indicates that much of the aerosol sampled during ARCPAC is partially acidic.

Figure 1 shows the geographical distribution of the different air mass types sampled by the WP-3D. Background and biomass burning air masses coexisted throughout northern Alaska at all altitudes sampled, but were sampled most frequently between 3.5 and $5.5 \mathrm{~km}$. Only a few anthropogenic pollution plumes were intercepted at similar altitudes to the biomass burning layers. It is important to note that the sampling strategy of the aircraft is reflected somewhat in this frequency distribution, as different air masses were specifically targeted during some research flights.

The average size distributions for the air mass types are shown in Fig. 2. Error bars denote the standard deviation in particle number concentration. The size distributions for all air mass types are dominated by the accumulation mode, with average geometric mean diameters of approximately $170 \mathrm{~nm}$ for all air mass types except for the biomass plumes, which were more variable $\left(D_{g}=189 \stackrel{\times}{\div} 1.19 \mathrm{~nm}\right)$ 


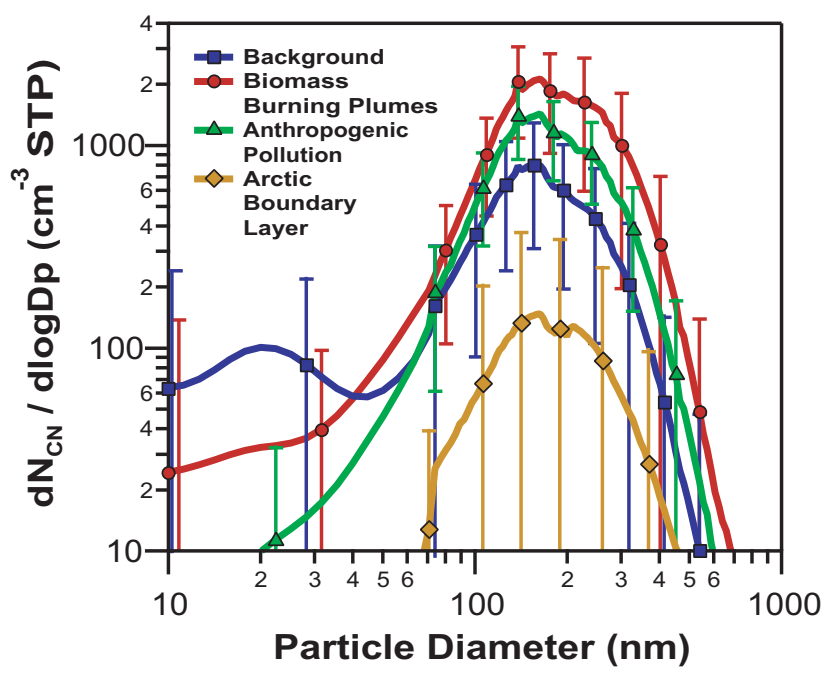

Fig. 2. Average dry particle size distributions for each air mass type sampled during 12-21 April. Error bars denote one standard deviation from the mean.

(Brock et al., 2011). A detailed comparison of the aerosol size distributions observed during ARCPAC and those found for the long-range transport of biomass burning emissions in other studies is given by Brock et al. (2011).

A much smaller nucleation mode $\left(D_{g}<50 \mathrm{~nm}\right)$ is also commonly present for the background case, but is reflected only as a very slight increase in the average concentration at smaller sizes in Fig. 2. Although the small features at the lower end of the size distributions $(<80 \mathrm{~nm})$ in Fig. 2 may not be statistically significant due to uncertainties from differencing the concentrations measured by adjacent NMASS channels, the background nucleation mode remains even after averaging over the five research flights, suggesting that it is likely real. Size distributions similar to the background case have been observed previously for the springtime Arctic atmosphere at Svalbard for well-aged, continental air masses transported northward from the mid-latitudes (e.g., Ström et al., 2003; Covert and Heintzenberg, 1993; Heintzenberg, 1980). Meanwhile, Shaw $(1983,1984)$ report a more significant nucleation mode for springtime Alaskan Arctic haze aerosol with concentrations on the order of those of the accumulation mode, which was also seen by Hegg et al. (1995) but at tenfold lower particle concentrations over the Arctic Ocean. Measurements also indicate that these Aitken and nucleation modes become increasingly dominant during the summer months as larger particles are removed via deposition and local sources become important (Korhonen et al., 2008; Heintzenberg et al., 2006; Ström et al., 2003; Hegg et al., 1996). Thus, the aerosols sampled during ARCPAC are representative of large, well-aged springtime Arctic pollution aerosol with a significant biomass burning influence. The strong biomass burning contribution even throughout the background air mass type means that while this back-

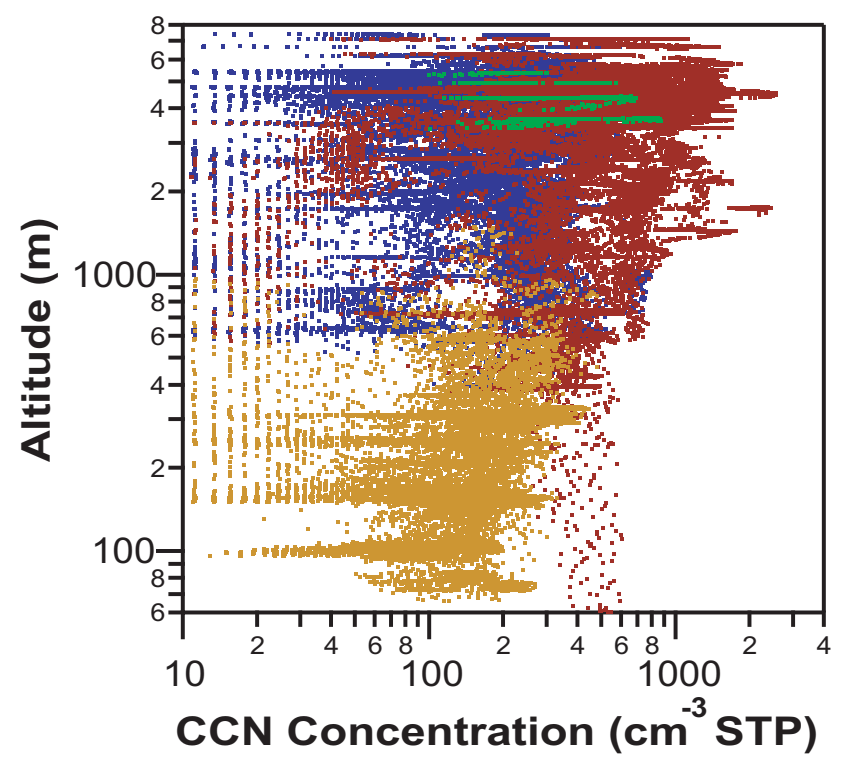

Fig. 3. Vertical profiles of $\mathrm{CCN}$ concentrations measured during ARCPAC. Data shown are $1 \mathrm{~Hz}$ measurements and are color-coded by air mass type as in Figs. 1 and 2.

ground is representative of the Alaskan Arctic during Spring 2008 when Asian wildfires were unusually early and frequent (Warneke et al., 2010), it is not necessary representative of the Arctic as a whole. In subsequent sections we evaluate the relative impacts of particle size and chemical composition on the $\mathrm{CCN}$ activity of these air mass types.

\subsection{CCN activity}

Vertical profiles of measured $\mathrm{CCN}$ concentration, $N_{\mathrm{CCN}}$, and fine particle condensation nucleus $\left(\mathrm{CN}, D_{p}>4 \mathrm{~nm}\right)$ concentration, $N_{\mathrm{CN}}$, for each air mass type are shown in Figs. 3 and 4, respectively. Fine particle concentrations were generally in the range of $100-1500 \mathrm{~cm}^{-3}$, and show little systematic dependence with altitude, except for the Arctic boundary layer air type, where $N_{\mathrm{CN}}$ increases by a factor of four with height over the first kilometer in altitude. Particle concentrations in the biomass burning plumes generally exceeded the background by roughly two-fold, and even larger enhancements can be observed in layers between $1500-3000 \mathrm{~m}$ (19 April) and at $4500 \mathrm{~m}$ (21 April). This structure is largely reflected in the CCN concentrations, which range from a few tens of particles per $\mathrm{cm}^{3}$ to concentrations on the order of $N_{\mathrm{CN}}$. While a small amount of this variability can be attributed to the range of water vapor supersaturations studied (0.1-0.6\%), low CCN concentrations were measured frequently at high supersaturations and vice versa.

As a quantitative comparison between $\mathrm{CCN}$ and $\mathrm{CN}$, activation curves showing the fraction of $\mathrm{CCN}$-active particles $\left(R_{\mathrm{a}}=N_{\mathrm{CCN}} / N_{\mathrm{CN}}\right)$, across the entire aerosol size distribution and as a function of instrument supersaturation, were 


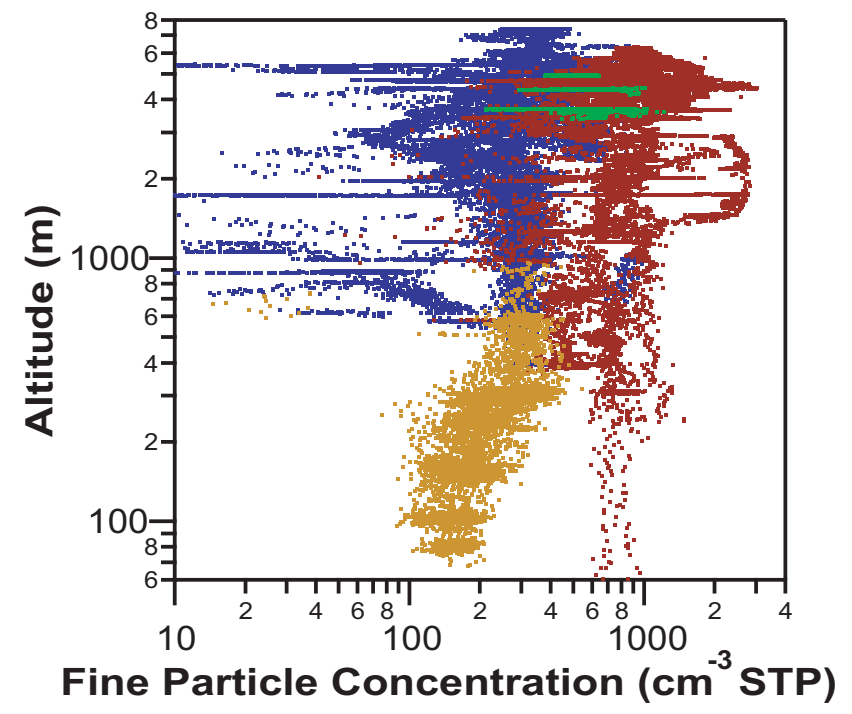

Fig. 4. Vertical profiles of fine particle $(\mathrm{CN})$ concentrations measured during ARCPAC. Data shown are $1 \mathrm{~Hz}$ measurements and are color-coded by air mass type as in Figs. 1 and 2 .

computed for each air mass type and are shown in Fig. 5. The circles and fitted trend lines in Fig. 5 denote the median activated fraction at each supersaturation, while the shaded area denotes the interquartile range. Black lines denote the theoretical activated fractions calculated for constant aerosol hygroscopicity, $\kappa$, using the average size distribution for each air mass type (discussed in Sect. 3.3). It can be seen that the activation curves are very similar across air mass types with a majority of particles acting as $\mathrm{CCN}$ above $0.1 \%$ supersaturation. Much of the similarity of these $\mathrm{CCN}$ activation curves can be attributed to the similarity of the aerosol size distributions; that is, size effects are more dominant than chemical effects in determining CCN activity (Dusek et al., 2006; Twomey, 1977b).

Compositional effects appear to become important at the $0.3-0.6 \%$ supersaturation range, where the activated fraction reaches a maximum, whose median value is less than unity. This suggests the presence of an externally-mixed, non-CCN-active aerosol fraction that constitutes approximately $0-20 \%$ of the aerosol number, and as much as $40 \%$ for the background air mass type where increased numbers of nucleation-mode particles were sometimes observed; although, the combined measurement uncertainties of $N_{\mathrm{CCN}}$ and $N_{\mathrm{CN}}(7-16 \%$ and $20 \%$, respectively), make this a weaker conclusion. For the background case, the maximum activated ratio is lower than the other cases because of the sub-40-nm nucleation mode, whose particles are too small to act as $\mathrm{CCN}$ regardless of their composition. Measurements of the sub-750-nm, single-particle number fractions from the PALMS, which are also shown in Fig. 5, indicate a nonnegligible dust fraction for all air mass types which would likely contribute to this non-CCN-active fraction, as well as less-oxidized organic species present as sulfate/organic or biomass/biofuel particle types. Previous Arctic studies have also detected the presence of a small, externally-mixed and less-hygroscopic aerosol mode either through humidified tandem differential mobility analyzer (HTDMA) measurements (e.g., Herich et al., 2009; Covert and Heintzenberg, 1993 ) or from inferences based on volatility measurements (e.g., Engvall et al., 2008; Hegg et al., 1996).

Past airborne and ground-based studies of springtime Arctic $\mathrm{CCN}$ have reported average concentrations in the range of $0-300 \mathrm{~cm}^{-3}$ and average activated fractions, $R_{\mathrm{a}}$, of $0.15-$ 0.63 for supersaturations of $0.3-1 \%$ (Yum and Hudson, 2001; Hegg et al., 1995; Shaw, 1986). Hegg et al. (1996) and later Kammermann et al. (2010) measured Arctic CCN during the summer and found higher CCN concentrations of $0-675 \mathrm{~cm}^{-3}$ and $R_{\mathrm{a}}$ of $0.10-0.17$ on average. This study finds 95th-percentile CCN concentrations of $100-550 \mathrm{~cm}^{-3}$ at $0.15-0.42 \%$ supersaturations for the background and Arctic boundary layer air mass types, which would be expected to be most representative of normal springtime Arctic conditions among the four air types encountered during ARCPAC. The large observed CCN concentrations appear to be more consistent with past summertime Arctic measurements than with the springtime studies. Fine particle concentrations are consistent with past springtime studies while the $\mathrm{CCN}$-active number fractions measured in this study are much higher. Thus, the enhancement in CCN likely results from a shift in the aerosol size distribution toward larger sizes rather than an overall increase in the total particle concentration. The 95thpercentile CCN concentrations at $0.15-0.42 \%$ supersaturations for the anthropogenic pollution and biomass burning air mass types were $300-800 \mathrm{~cm}^{-3}$ and $500-1500 \mathrm{~cm}^{-3}$, respectively.

\subsection{Inferring hygroscopicity}

The ability of a particle to act as a $\mathrm{CCN}$ depends on its size and chemical composition and on the ambient water vapor supersaturation. This relationship is described by Köhler theory (Köhler, 1936), and a single parameter representation of this theory has been recently developed and widely-adopted (Petters and Kreidenweis, 2007). The critical water vapor supersaturation that a particle must be exposed to to act as a $\mathrm{CCN}, s_{\mathrm{c}}$, is given by

$s_{\mathrm{c}} \approx \sqrt{\frac{4}{\kappa D_{p}^{3}}\left(\frac{4 \sigma M_{\mathrm{w}}}{3 R T \rho_{\mathrm{w}}}\right)^{3}}$

where $D_{p}$ is the dry particle diameter, $\kappa$ is the hygroscopicity parameter (Petters and Kreidenweis, 2007), $R$ is the gas constant, $T$ is the absolute temperature, $\sigma$ is the surface tension of the solution droplet, and $M_{\mathrm{w}}$ and $\rho_{\mathrm{w}}$ are the molar mass and density of water, respectively. Although organic surfactants present in atmospheric aerosols can depress the droplet surface tension below that of pure water (Asa-Awuku et al., 

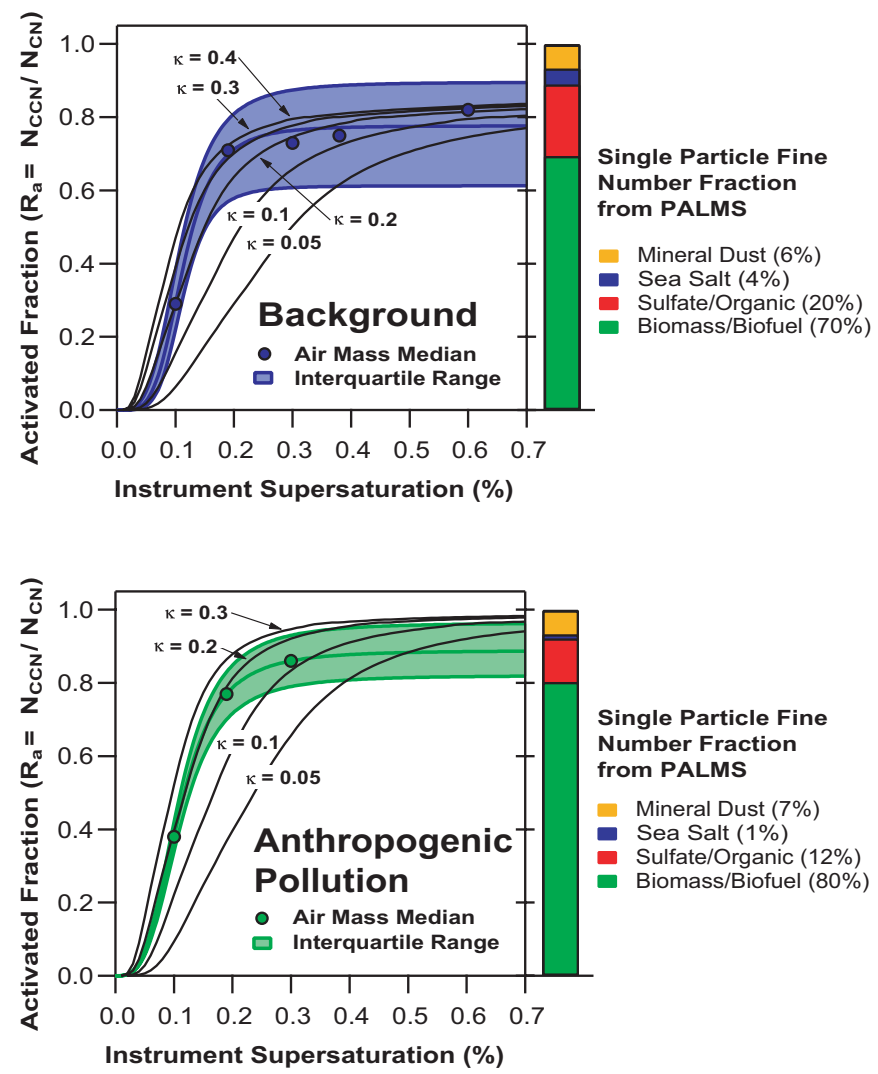
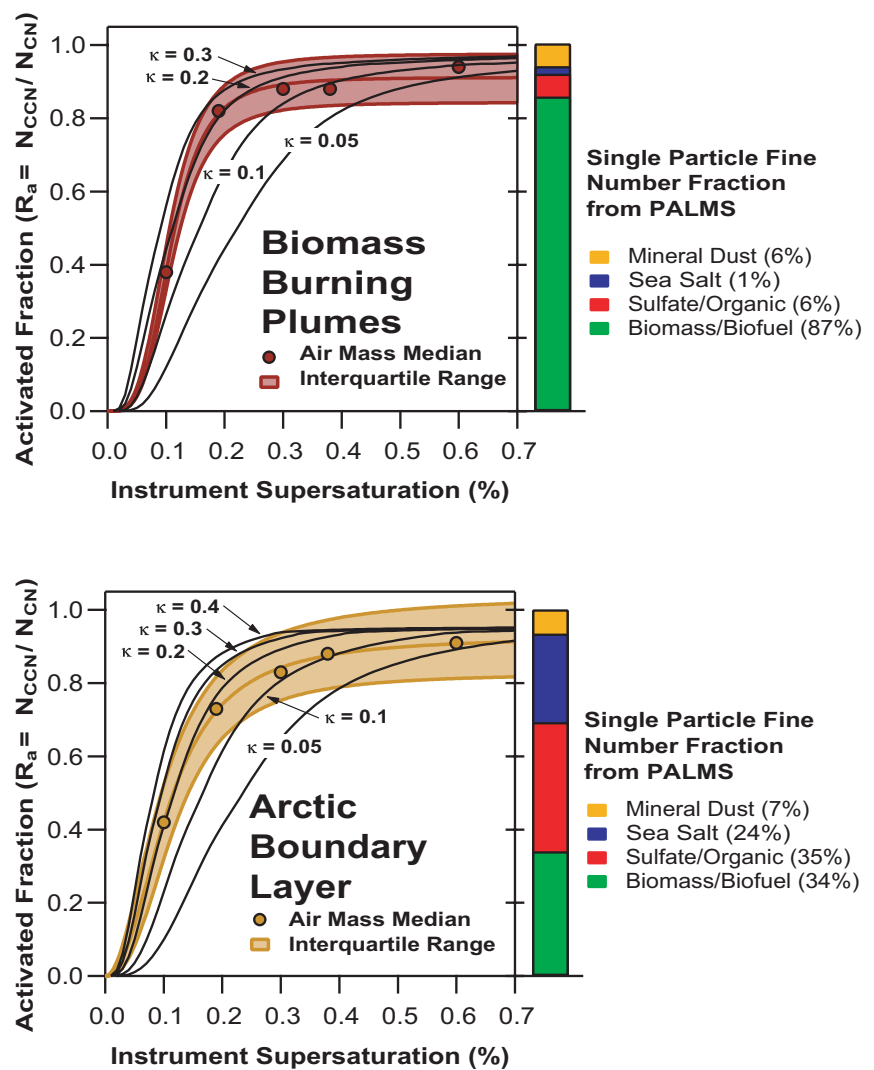

Fig. 5. Median CCN activated fraction $\left(R_{\mathrm{a}}=N_{\mathrm{CCN}} / N_{\mathrm{CN}}\right)$ as a function of instrument supersaturation for each air mass sampled during 12-21 April. Thick, colored curves are sigmoidal fits of the form $R_{\mathrm{a}}=a_{0} /\left(1+\left(s / a_{1}\right)^{-a_{3}}\right)$, where $a_{0}, a_{1}$, and $a_{2}$ are fitting constants, and the shaded region in the figure is the interquartile range. Thin, black lines denote constant values of the hygroscopicity parameter, $\kappa$, computed based on the average size distribution for each air mass type. The stacked bars show the number fraction of each particle type from the PALMS instrument for particle diameters of 150-750 nm.

2009; Decesari et al., 2003; Facchini et al., 1999), most field measurement studies, including this one, assume the surface tension of water in Eq. (1) by convention.

An alternate and equivalent way of expressing Eq. (1) is to state that when particles with a given $\kappa$ are exposed to a constant water vapor supersaturation, those particles larger than some critical dry diameter, $D_{\mathrm{p}, \mathrm{c}}$ will act as $\mathrm{CCN}$. Thus, we can infer $\kappa$ directly from measurements of $\mathrm{CCN}$ and the particle size distribution by first determining $D_{\mathrm{p}, \mathrm{c}}$ by integrating the particle size distribution to match the measured $\mathrm{CCN}$ concentration at a specified supersaturation,

$N_{\mathrm{CCN}}=\int_{D_{\mathrm{p}, \mathrm{c}}}^{\infty} n_{\mathrm{CN}} d D_{p}$

where $N_{\mathrm{CCN}}$ is the measured $\mathrm{CCN}$ number concentration and $n_{\mathrm{CN}}$ is the particle size distribution function. The derived $D_{\mathrm{p}, \mathrm{c}}$ for each supersaturation is then substituted into Eq. (1) to find $\kappa$. Implicit in this method is the assumption that the aerosols larger than $D_{\mathrm{p}, \mathrm{c}}$ are internally-mixed. Given that $\kappa$ is most sensitive to sizes around $D_{\mathrm{p}, \mathrm{c}}$, we expect that the $\kappa$ derived in this way is most characteristic of particles with size $D_{\mathrm{p}, \mathrm{c}}$.

Inferred median $\kappa$ values from the $\mathrm{CCN}$ and size distribution measurements are plotted against their corresponding values of $D_{\mathrm{p}, \mathrm{c}}$ in Fig. 6; error bars denote the interquartile range of inferred values. Also shown for comparison are predicted $\kappa$ values from size-averaged and size-resolved C-ToFAMS compositions calculated as

$\kappa=\sum_{i} \epsilon_{i} \kappa_{i}$

where $\epsilon_{i}$ and $\kappa_{i}$ are the volume fraction and pure-component hygroscopicity of species $i$, respectively. Values of $\kappa_{i}$ were found from

$\kappa_{i}=\left(\rho_{i} / M_{i}\right)\left(M_{\mathrm{w}} / \rho_{\mathrm{w}}\right) v_{i}$

where $\rho_{i}, M_{i}$, and $v_{i}$ are the density, molar mass, and van't Hoff factor of the pure solute, respectively. An organic $\kappa$ of 0.11 was assumed, which corresponds to a theoretical organic species with a molar mass of $0.200 \mathrm{~kg} \mathrm{~mol}^{-1}$, density of $1400 \mathrm{~kg} \mathrm{~m}^{-3}$ (King et al., 2007), and a van't Hoff factor of unity. 

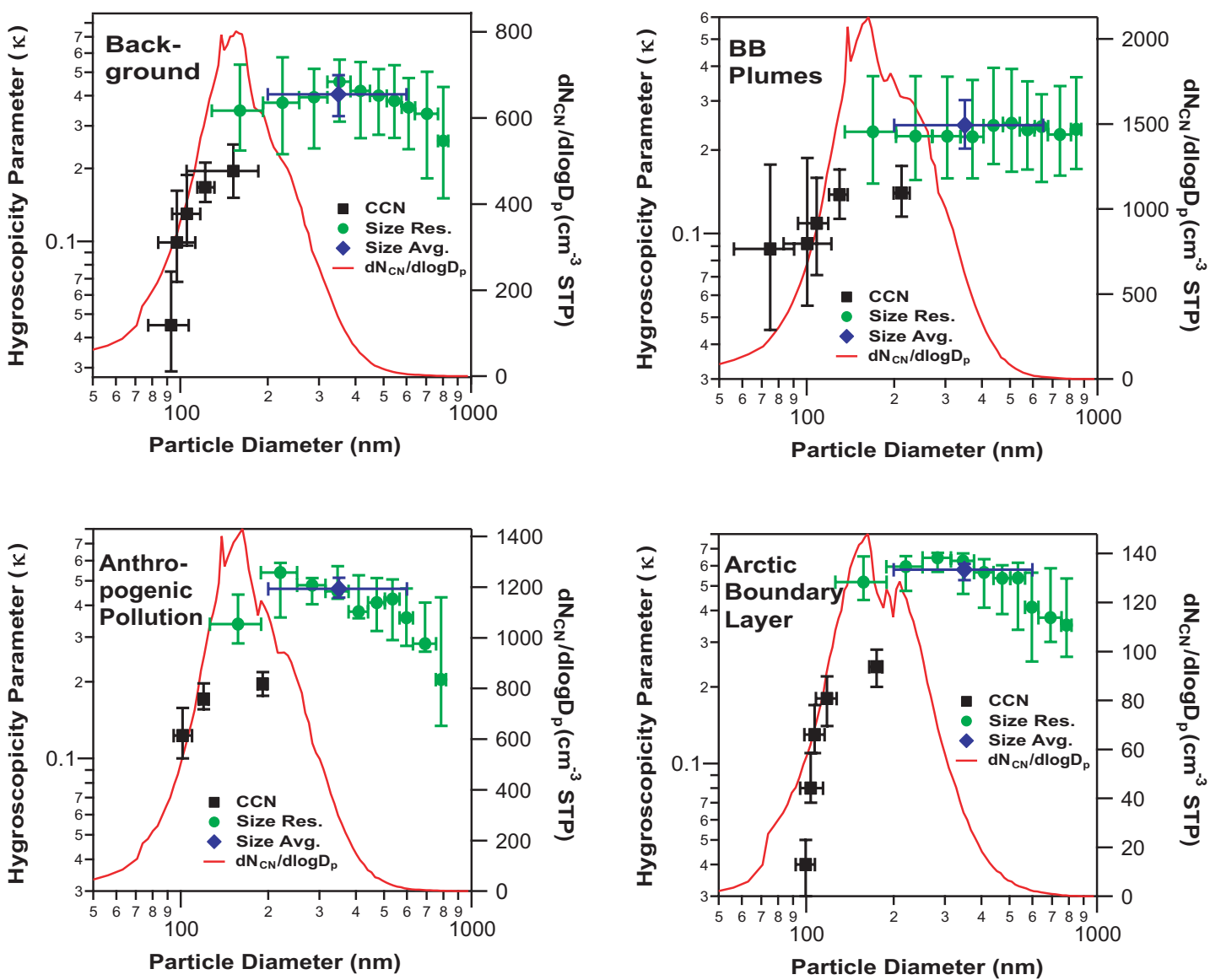

Fig. 6. Inferred values of the hygroscopicity parameter, $\kappa$, obtained from the measured CCN concentrations and size distributions and plotted against the critical activation diameter, $D_{\mathrm{p}, \mathrm{c}}$ (squares). Also shown are $\kappa$ values calculated for particle compositions obtained from sizeresolved (circles) and size-averaged (diamonds) C-ToF-AMS measurements. Markers denote the median values for each air mass type, while error bars denote the interquartile range. The solid line shows the average particle size distribution from Fig. 2 (on linear scale).

It is apparent from Fig. 6 that the CCN-derived hygroscopicities are substantially lower than those suggested by the non-refractory aerosol composition, and these values also show a strong size-dependence. This apparent discrepancy could reflect size-dependent chemistry, where less-soluble organics are enhanced in the smaller particles relative to the larger particles measured by the C-ToF-AMS. For example, Kammermann et al. (2010) found similar $\kappa$ values of 0.070.21 for accumulation mode aerosol $(D=50-200 \mathrm{~nm}) \mathrm{sam}$ pled in the remote subarctic Stordalen mire in northern Sweden using a DMT CCNC and a hygroscopicity tandem differential mobility analyzer (HTDMA). Alternatively, the lower $\kappa$ could reflect the presence of an externally-mixed, non$\mathrm{CCN}$-active aerosol mode such as insoluble organics or even mineral dust, which constitutes $\sim 6 \%$ by number (Fig. 5). Since the hygroscopicities shown in Fig. 6 were calculated assuming an internally-mixed aerosol, the presence of this less-CCN-active mode would serve to decrease $\kappa$. This is especially true for the lowest values of the $\mathrm{CCN}$-derived $\kappa(s>$ $0.3 \%$ ), where all of the $\mathrm{CCN}$-active particles have already ac- tivated and the effect of a less-hygroscopic mode would disproportionately affect predictions made assuming an internal mixture. The derived hygroscopicities of 0.1-0.3 in this study are consistent with those of an aged, pyrogenic aerosol (Andreae and Rosenfeld, 2008), which is not surprising given the influence of biomass burning aerosol, present in all air mass types sampled.

\subsection{Hygroscopicity and Organic Oxygenation}

It was also observed during ARCPAC that the geometric mean diameter of the aerosol size distribution varied with carbon monoxide mixing ratio for the biomass burning and background air types (Figure 8 in Brock et al., 2011), and it was suggested that dilution of the biomass burning aerosols may evaporate some semi-volatile organic species present in these particles (Brock et al., 2011). An alternate explanation would be that the plumes were emitted with lower gas-phase concentrations or were diluted early in transport, leading to less secondary aerosol production and smaller particles. 


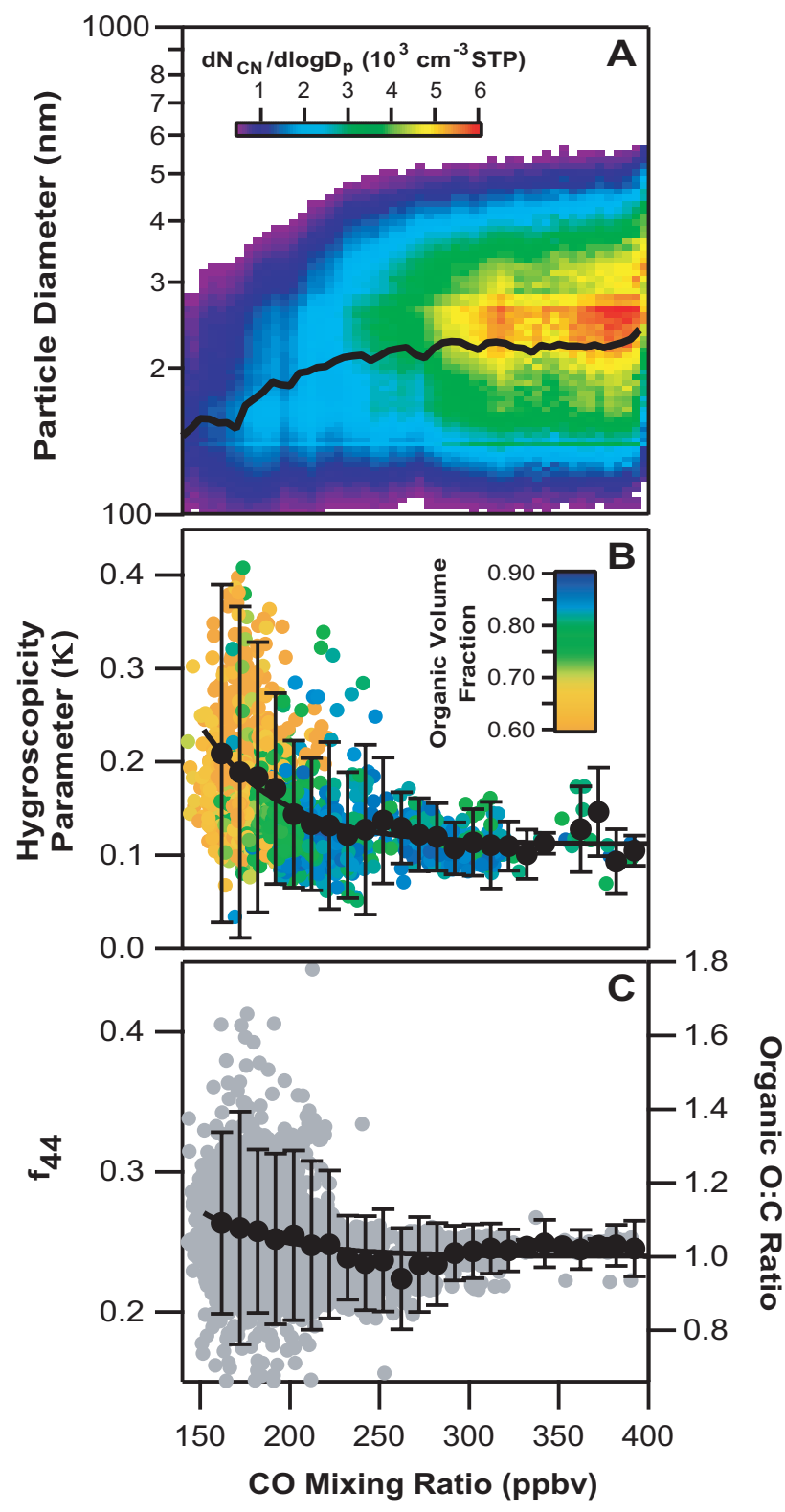

Fig. 7. (a) Average particle size distribution for all biomass burning plumes sampled, colored by number concentration, and plotted versus $\mathrm{CO}$ mixing ratio. The black trace denotes the distribution geometric mean diameter. (b) $\mathrm{CCN}$-derived biomass burning aerosol hygroscopicity, colored by aerosol organic volume fraction from the C-ToF-AMS, and plotted versus CO mixing ratio. (c) $f_{44}$ ratio obtained from the C-ToF-AMS (averaged to 5-minute intervals) plotted versus $\mathrm{CO}$ mixing ratio. The black-circles in (b) and (c) denote the mean $\kappa$ and error bars represents one standard deviation from the mean.

$\mathrm{CCN}$ and large particle concentrations were also found to correlate linearly with CO (Lance et al., 2011). It would be expected that the least volatile organic species would be the most oxidized, and hence most $\mathrm{CCN}$-active, while the semi-volatile organics would be less-oxidized and therefore

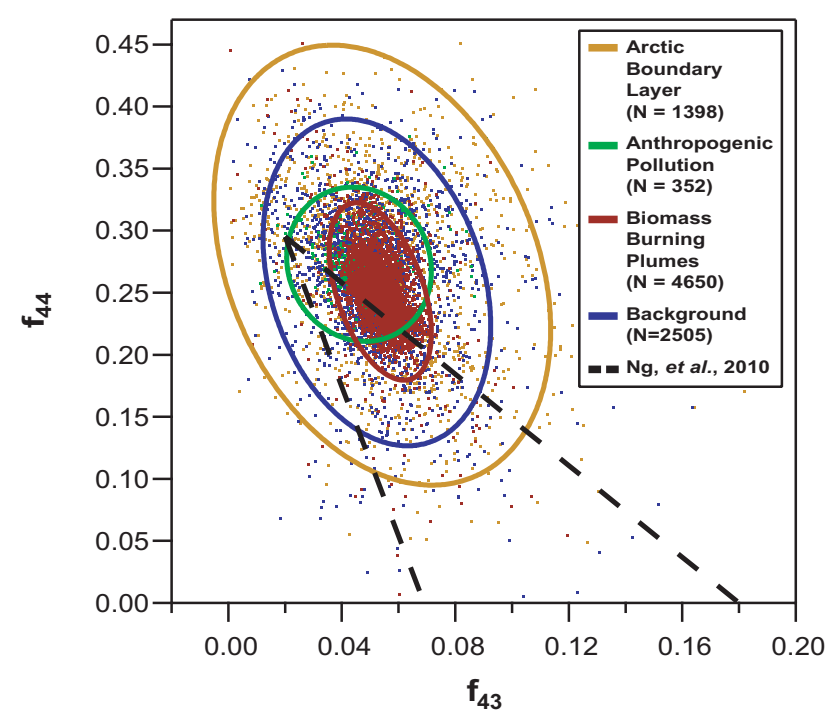

Fig. 8. Oxidation state of the aerosol expressed as $f_{44}$ versus $f_{43}$, following ( $\mathrm{Ng}$ et al., 2010). Points denote the 10-second-averaged observations for each air mass type, and the ellipses denote the $95 \%$ confidence regions. Dashed lines are the parameterized triangular bounding region reported by ( $\mathrm{Ng}$ et al., 2010) for SOA chamber oxidation and ambient measurements.

less CCN-active (Duplissy et al., 2011; Chang et al., 2010; Jimenez et al., 2009). To test this assumption, Figure 7 shows the average aerosol size distribution and hygroscopicities plotted versus the $\mathrm{CO}$ mixing ratio for all biomass burning plumes encountered during ARCPAC. A notable decrease in the aerosol geometric mean diameter and number concentration is apparent with decreasing $\mathrm{CO}$, and this trend coincides with an increase in the average $\kappa$ from 0.1 to 0.2 and increased variability of $\kappa$. While the decrease in organic volume fraction, and corresponding increase in the higher$\kappa$ inorganic fraction is sufficient to explain this behavior, a slight shift in the degree of organic oxidation toward moreoxidized aerosol was also observed. The C-ToF-AMS mass fraction of the $m / z 44$ peak (mostly the $\mathrm{CO}_{2}^{+}$fragment of highly oxygenated organics such as, e.g., di-acids and esters) to total organic mass, $f_{44}$, is correlated with the organic O:C ratio (Aiken et al., 2008; Zhang et al., 2005), which, in turn, relates to the organic hygroscopicity (Jimenez et al., 2009). This is shown for the biomass burning plumes in Fig. 7c. The relationship between $f_{44}$ and the O:C ratio was calculated using the correlation of Aiken et al. (2008). In biomass burning plumes an average $f_{44}$ of $\sim 0.26 \pm 0.03$ was observed, and the average $f_{44}$ increased very slightly from $0.24 \pm 0.02$ to 0.27 \pm 0.06 as $\mathrm{CO}$ decreased from $\sim 400 \mathrm{ppbv}$ to $150 \mathrm{ppbv}$. The very small change in $f_{44}$ and $\kappa$ with $\mathrm{CO}$ lends support to the early dilution / reduced SOA formation explanation versus evaporation of less-oxidized, semi-volatile species during later plume dilution. 
Figure 8 shows the $95 \%$-percent simultaneous confidence ellipses for $f_{44}$ and $f_{43}$, where $f_{43}$ is the ratio of the $\mathrm{m} / \mathrm{z}$ 43 peak (mostly $\mathrm{C}_{3} \mathrm{H}_{7}^{+}$and $\mathrm{C}_{2} \mathrm{H}_{3} \mathrm{O}^{+}$fragments) to the total organic mass. The center of each ellipse denotes the mean values of $f_{43}$ and $f_{44}$. Also shown in Fig. 8 is the triangular bounding region reported by $\mathrm{Ng}$ et al. (2010) that encompasses ambient and chamber data for oxygenated organic aerosol (OOA). While $\mathrm{Ng}$ et al. (2010) define $f_{X}$ as the ratio of $m / z, X$ to only the oxygenated organic aerosol mass and this study uses the total organic mass measured by the C-ToF-AMS, direct comparison is reasonable because of the expected dominance of OOA (versus hydrocarbon-like organics) in the aged air masses sampled during ARCPAC. This assumption may explain why the ARCPAC confidence ellipses are shifted slightly toward larger $f_{43}$ values relative to the triangular region.

Most organic aerosols sampled during ARCPAC exhibited $f_{44}>0.15$, indicative of well-oxygenated species $(\mathrm{O}: \mathrm{C} \sim 0.8-$ 1.2 using the correlation of Aiken et al. (2008)). Model atmospheric compounds with $\mathrm{O}: \mathrm{C}$ ratios in this range include succinic, glutaric, and malic acids, although these model species have slightly lower molar masses $\left(0.118 \mathrm{~kg} \mathrm{~mol}^{-1}\right.$, $0.132 \mathrm{~kg} \mathrm{~mol}^{-1}$, and $0.134 \mathrm{~kg} \mathrm{~mol}^{-1}$, respectively) than the average organic molar mass inferred from $\kappa$ during ARCPAC $\left(\sim 0.200 \mathrm{~kg} \mathrm{~mol}^{-1}\right)$. Jimenez et al. (2009) have shown that the organic hygroscopicity varies linearly with the $\mathrm{O}: \mathrm{C}$ ratio for biogenic organics in smog chambers and for a number of field studies. Extrapolating the Jimenez et al. (2009) parameterization to $\mathrm{O}: \mathrm{C} \sim 1.0$ implies an organic $\kappa$ of $\sim 0.43$, which is significantly greater than the hygroscopicities inferred here. This suggests that increased organic oxygenation via aging processes may increase hygroscopicity only up to a point $(\kappa \sim 0.2-0.3)$, after which the organic hygroscopicity is less sensitive to the $\mathrm{O}: \mathrm{C}$ ratio. Despite uncertainties with regard to the aerosol mixing state, the high $\mathrm{O}: \mathrm{C}$ ratios and lower hygroscopicities observed here may suggest, apart from the different aerosol sources, a different secondary organic aerosol formation pathway than purely gas-phase oxidation chemistry. The ubiquity of Arctic clouds and recent modeling simulations showing oxalate concentrations of 20$30 \%$ that of sulfate in the Arctic suggest that this formation pathway may be through aqueous phase chemistry (Myriokefalitakis et al., 2011), which can produce both organic acids in cloud droplets and multi-functional humic-like substances with O:C ratio $\sim 1$ in wet aerosols (Lim et al., 2010; Ervens et al., 2004).

\subsection{Sensitivity of CCN to Composition Effects}

While being consistent with previous studies of pyrogenic aerosol, the hygroscopicities inferred in Sect. 3.3 are notably lower than expected from the C-ToF-AMS measurements, especially at higher supersaturations. However, given that most particles have activated already above about $0.1 \%$ supersaturation (see Figure 5), it is unclear how important these differences in $\kappa$ are for $\mathrm{CCN}$ concentrations. Here, we assess the sensitivity of $\mathrm{CCN}$ concentrations to composition effects using parameters typical of those measured during ARCPAC.

The sensitivity of CCN concentrations to changes in chemical composition can be computed analytically by first using Equation 1 to find the sensitivity of $D_{\mathrm{p}, \mathrm{c}}$ to $\kappa$, and then determining the sensitivity of $\mathrm{CCN}$ concentration to changes in $D_{\mathrm{p}, \mathrm{c}}$ determined by the steepness of the size distribution function:

$\frac{\partial N_{\mathrm{CCN}}}{\partial \kappa}=\left(\frac{\partial D_{\mathrm{p}, \mathrm{c}}}{\partial \kappa}\right)\left(\frac{\partial N_{\mathrm{CCN}}}{\partial D_{\mathrm{p}, \mathrm{c}}}\right)$

Differentiating Eq. (1) yields

$\frac{\partial D_{\mathrm{p}, \mathrm{c}}}{\partial \kappa}=\frac{-D_{\mathrm{p}, \mathrm{c}}}{3 \kappa}$

For simplicity, we assume here that the aerosol sizedistribution is lognormal as

$n_{\mathrm{CN}}=\frac{N_{\mathrm{CN}}}{\sqrt{2 \pi} D_{p} \ln \sigma_{g}} \exp \left(\frac{-\ln ^{2}\left(D_{p} / D_{g}\right)}{2 \ln ^{2} \sigma_{g}}\right)$

where $D_{g}$ is the geometric mean diameter of the size distribution and $\sigma_{g}$ is the geometric standard deviation. Substituting Equation 7 into Eq. (2) and differentiating with respect to $D_{\mathrm{p}, \mathrm{c}}$ gives

$\frac{\partial N_{\mathrm{CCN}}}{\partial D_{\mathrm{p}, \mathrm{c}}}=\frac{-N_{\mathrm{CN}}}{\sqrt{2 \pi} D_{\mathrm{p}, \mathrm{c}} \ln \sigma_{\mathrm{g}}} \exp \left(\frac{-\ln ^{2}\left(D_{\mathrm{p}, \mathrm{c}} / D_{g}\right)}{2 \ln ^{2} \sigma_{g}}\right)$

Finally, substituting Equations 6 and 8 into Eq. (5) and incorporating $\kappa$ and $N_{\mathrm{CN}}$ into the left-hand-side yields the sensitivity of the activated ratio, $R_{\mathrm{a}}$, as

$\frac{\partial R_{\mathrm{a}}}{\partial \ln \kappa}=\frac{1}{3 \sqrt{2 \pi} \ln \sigma_{g}} \exp \left(\frac{-\ln ^{2}\left(D_{\mathrm{p}, \mathrm{c}} / D_{g}\right)}{2 \ln ^{2} \sigma_{g}}\right)$

Equation (9) is expressed in terms of the size distribution constants and $D_{\mathrm{p}, \mathrm{c}}$, which depends on $s$ and $\kappa$. Thus, for a given $\kappa$, we can express $\partial R_{\mathrm{a}} / \partial \ln \kappa$ across the range of relevant supersaturations. This is shown in Fig. 9 for $D_{g}=170 \mathrm{~nm}$ and $\sigma_{g}=1.5$, which are values representative of the average size distributions for the background, anthropogenic pollution, and Arctic boundary layer air mass types (Brock et al., 2011)

The $\log$-normal nature of $\partial R_{\mathrm{a}} / \partial \ln \kappa$ can be interpreted as that $R_{\mathrm{a}}$ is most sensitive to composition effects when $D_{\mathrm{p}, \mathrm{c}}$ is near the maximum of the size distribution, where a small change in $D_{\mathrm{p}, \mathrm{c}}$ translates into a larger change in CCN than at the tails of the distribution. This is also true in $s$-space for a constant value of $\kappa$. The curves for $\kappa=0.1-0.2$ shown in Fig. 9 indicate that $\mathrm{CCN}$ concentrations are most sensitive to composition effects near $s \sim 0.1-0.2$, because this combination of $s$ and $\kappa$ produces values of $D_{\mathrm{p}, \mathrm{c}} \sim D_{g}$. 


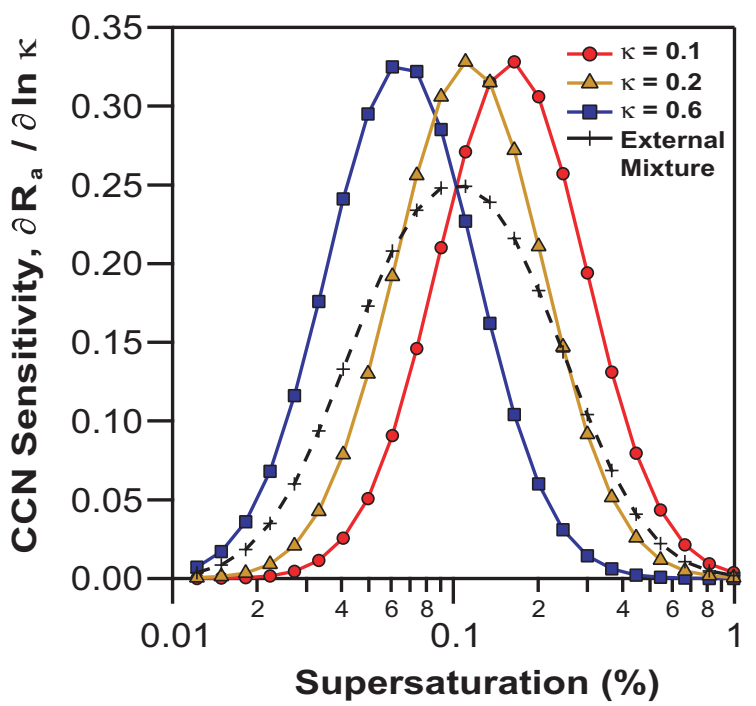

Fig. 9. Sensitivity of $R_{\mathrm{a}}$ to $\kappa$ as a function of superaturation. Solid traces were computed assuming an internal mixture and constant values of $\kappa$, while the dashed trace represents an external mixture of $50 \%$ inorganic aerosol $(\kappa=0.6)$ and $50 \%$ organic aerosol $(\kappa=0.1)$, by number.

The dashed curve in Fig. 9 shows the approximate CCN sensitivity of an externally-mixed aerosol with the same lognormal size distribution as before, but now with $50 \%$ inorganic particles $(\kappa=0.6)$ and $50 \%$ organic particles $(\kappa=0.1)$, by number. This is computed as the sum of the individual modal sensitivity distributions weighted by the number fraction of each mode. The externally-mixed case shows a similar sensitivity to that of the internally-mixed case with $\kappa=0.2$, but with a slightly wider distribution in $s$-space.

This analysis implies that weakly-forced Arctic stratiform clouds with maximum supersaturations of around 0.1-0.2\% are at the peak of sensitivity to aerosol chemical composition effects.

\subsection{CCN closure}

In this section, we use chemical compositions from the CToF-AMS and the measured size distributions to quantify the uncertainty associated with $\mathrm{CCN}$ predictions and to test the impacts of mixing state and solubility assumptions commonly employed in models. Such "CCN closure" analyses are commonplace in the literature and typical reported overprediction uncertainties range from 0-20\% (e.g., AsaAwuku et al., 2011; Rose et al., 2010; Wang et al., 2010; Bougiatioti et al., 2009; Broekhuizen et al., 2006; Rissler et al., 2004; VanReken et al., 2003, and others).

The C-ToF-AMS was not operational during the April 12th flight, so we restrict our analysis to the flights on April 15th, 18th, 19th, and 21st. Only the April 19th flight examined supersaturations above $0.3 \%$, so we also restrict our analysis here to water vapor supersaturations of $0.1,0.2$, and $0.3 \%$. Finally, because of relatively low aerosol mass loadings at particle diameters less than $150-200 \mathrm{~nm}$, the resolution of the C-ToF-AMS is too noisy to assess closure using size-resolved composition measurements as has been performed by some previous studies in more polluted environments (e.g., Asa-Awuku et al., 2011; Medina et al., 2007), and size-invariant chemistry is assumed for this analysis. From Figure 6 it can be seen that the size-averaged and size-resolved compositions yield similar values of $\kappa$ over the diameter range of $200-800 \mathrm{~nm}$, as this is where the mass distribution is located, which would seem to support the size-invariance assumption; however, it is an open question whether the measured particle composition at these sizes is the same as at smaller sizes.

$\mathrm{CCN}$ concentrations are predicted as follows. First, CToF-AMS mass loadings are used to find the volume fractions of organics, ammonium nitrate, ammonium sulfate, ammonium bisulfate, and sulfuric acid, where the inorganic species are partitioned as described in Sect. 3.1. Then, Equations 3 and 4 are used to find the overall hygroscopicity of the aerosol, which is used in Equation 1 to find the critical activation diameter, $D_{\mathrm{p}, \mathrm{c}}$, above which particles will act as CCN.

In applying Eqs. (1), (3), and (4), it is necessary to make an assumption about the aerosol mixing state. For example, one can assume that the aerosols are internally mixed with a composition that yields one $D_{\mathrm{p}, \mathrm{c}}$ for the entire population, and $N_{\mathrm{CCN}}$ is found directly from Eq. (2).

Alternatively, one can assume that the aerosol are externally mixed, where each particle contains either only organic species or only inorganic species, and the number fraction of each particle type is described by the overall volume fractions. In this case, two distinct particle populations exist, each with their own $D_{\mathrm{p}, \mathrm{c}}$. Since the organic species are less hygroscopic than the inorganic species, $D_{\mathrm{p}, \mathrm{c}, \text { org }}>D_{\mathrm{p}, \mathrm{c} \text {, inorg }}$, and

$$
\begin{aligned}
N_{\mathrm{CCN}}= & \int_{D_{p, c, i n o r g}}^{D_{p, c, o r g}}\left(1-\epsilon_{\text {org }}\right) n_{\mathrm{CN}} d D_{p} \\
& +\int_{D_{p, c, \text { org }}}^{\infty} n_{\mathrm{CN}} d D_{p}
\end{aligned}
$$

Equation (10) treats all particles (both organic and inorganic) larger than $D_{\mathrm{p}, \mathrm{c} \text {,org }}$ as $\mathrm{CCN}$, while only the inorganic fraction of particles with diameters between $D_{\mathrm{p}, \mathrm{c} \text {, inorg }}$ and $D_{\mathrm{p}, \mathrm{c} \text {, org }}$ are counted as CCN.

In addition, it is necessary to make an assumption regarding the hygroscopicity of the organic species. In this analysis we test two cases: one where the organic particle fraction can be assumed to be slightly soluble $(\kappa=0.11)$ and one where the organic particle fraction is assumed to be completely insoluble $(\kappa=0)$. Given the aged nature of the organics, the latter assumption is unlikely, but still a useful sensitivity scenario. Closure is reported 
Table 1. Percent overprediction $(\Phi-1) \times 100 \%$ in CCN number concentration from different organic solubility and mixing state assumptions. Data from the CCNC, C-ToF-AMS, and size distributions were averaged over 10-s periods, and $\mathrm{N}$ reflects the number of $0.1-\mathrm{Hz}$ data points used to calculate each mean and standard deviation.

\begin{tabular}{|c|c|c|c|c|c|c|}
\hline \multirow[b]{2}{*}{ Air Mass Type } & \multirow[b]{2}{*}{$\mathrm{N}$} & \multicolumn{2}{|c|}{ Internal Mixture } & \multicolumn{2}{|c|}{ External Mixture } & \multirow{2}{*}{$\begin{array}{c}\text { Size } \\
\text { Dependent } \\
\text { Mixture }^{a}\end{array}$} \\
\hline & & $\begin{array}{l}\text { Soluble } \\
\text { Organics }\end{array}$ & $\begin{array}{l}\text { Insoluble } \\
\text { Organics }\end{array}$ & $\begin{array}{c}\text { Soluble } \\
\text { Organics }\end{array}$ & $\begin{array}{l}\text { Insoluble } \\
\text { Organics }\end{array}$ & \\
\hline \multicolumn{7}{|l|}{ Anthropogenic Pollution } \\
\hline$s=0.1 \pm 0.04(\%)$ & 93 & $81 \pm 22$ & $73 \pm 22$ & $20 \pm 20$ & $9 \pm 22$ & $44 \pm 20$ \\
\hline$s=0.2 \pm 0.04(\%)$ & 77 & $20 \pm 10$ & $19 \pm 10$ & $-7 \pm 8$ & $-31 \pm 11$ & $-7 \pm 8$ \\
\hline$s=0.3 \pm 0.04(\%)$ & 53 & $13 \pm 9$ & $13 \pm 9$ & $-1 \pm 8$ & $-35 \pm 9$ & $-1 \pm 8$ \\
\hline \multicolumn{7}{|c|}{ Biomass Burning Plumes } \\
\hline$s=0.1 \pm 0.04(\%)$ & 1088 & $47 \pm 27$ & $18 \pm 25$ & $-12 \pm 16$ & $-65 \pm 21$ & $17 \pm 18$ \\
\hline$s=0.2 \pm 0.04(\%)$ & 540 & $16 \pm 10$ & $9 \pm 10$ & $-4 \pm 9$ & $-70 \pm 14$ & $-4 \pm 9$ \\
\hline$s=0.3 \pm 0.04(\%)$ & 267 & $12 \pm 8$ & $9 \pm 7$ & $3 \pm 9$ & $-67 \pm 12$ & $3 \pm 9$ \\
\hline \multicolumn{7}{|l|}{ Background } \\
\hline$s=0.1 \pm 0.04(\%)$ & 471 & $95 \pm 79$ & $79 \pm 77$ & $21 \pm 45$ & $-4 \pm 48$ & $48 \pm 51$ \\
\hline$s=0.2 \pm 0.04(\%)$ & 298 & $34 \pm 37$ & $30 \pm 33$ & $3 \pm 26$ & $-30 \pm 30$ & $3 \pm 27$ \\
\hline$s=0.3 \pm 0.04(\%)$ & 282 & $19 \pm 13$ & $17 \pm 13$ & $3 \pm 11$ & $-47 \pm 21$ & $3 \pm 11$ \\
\hline \multicolumn{7}{|l|}{ Arctic Boundary Layer } \\
\hline$s=0.1 \pm 0.04(\%)$ & 76 & $61 \pm 18$ & $55 \pm 21$ & $15 \pm 19$ & $1 \pm 28$ & $35 \pm 18$ \\
\hline$s=0.2 \pm 0.04(\%)$ & 64 & $38 \pm 13$ & $37 \pm 13$ & $17 \pm 13$ & $3 \pm 18$ & $19 \pm 14$ \\
\hline$s=0.3 \pm 0.04(\%)$ & 41 & $41 \pm 9$ & $41 \pm 9$ & $29 \pm 9$ & $10 \pm 16$ & $29 \pm 9$ \\
\hline \multicolumn{7}{|l|}{ All Air Mass Types } \\
\hline$s=0.1 \pm 0.04(\%)$ & 1715 & $62 \pm 52$ & $39 \pm 53$ & $0 \pm 31$ & $-42 \pm 43$ & $27 \pm 34$ \\
\hline$s=0.2 \pm 0.04(\%)$ & 955 & $23 \pm 24$ & $18 \pm 23$ & $-1 \pm 17$ & $-50 \pm 31$ & $0 \pm 18$ \\
\hline$s=0.3 \pm 0.04(\%)$ & 623 & $17 \pm 13$ & $15 \pm 13$ & $5 \pm 12$ & $-51 \pm 26$ & $5 \pm 12$ \\
\hline
\end{tabular}

a Particles with $D_{p}>200 \mathrm{~nm}$ assumed to be internally mixed, while particles with $D_{p}<200 \mathrm{~nm}$ are externally mixed. Organics are assumed to be soluble.

in this section in terms of a $\mathrm{CCN}$ prediction error ratio, $\Phi=N_{\mathrm{CCN}, \text { predicted }} / N_{\mathrm{CCN}}$.

$\mathrm{CCN}$ predictions tended toward overprediction, and the average percent overprediction for each supersaturation and air mass type is shown in Table 1. Overall, the largest discrepancies between predicted and measured concentrations were observed at $s=(0.1 \pm 0.4) \%$. This is consistent with Figs. 5 and 9; a small change in $\kappa$ at $\sim 0.1 \%$ supersaturation would cause a large change in the activated fraction, and hence $\mathrm{CCN}$ concentration. Assuming the aerosol to be internally-mixed with soluble organics produced the largest overprediction of the four models tested, and treating the organics as insoluble reduced this overprediction only slightly. Assuming the aerosol to be externally-mixed with soluble organics resulted in a reasonable overall closure $(\Phi \sim 1-1.2$ for all air mass types), which was worsened substantially by assuming that organics were insoluble $(\Phi \sim 0.5$ for all air mass types).

Thus, assuming Arctic aerosol to be composed of an external mixture of soluble organic and inorganic particles al- lowed prediction of $\mathrm{CCN}$ concentrations to within roughly $0-20 \%$, on average. This was also true for the individual air mass types, except for within the Arctic boundary layer, where assuming insoluble organics further improved closure. The good closure obtained from assuming an externally-mixed aerosol is somewhat unexpected, considering the long lifetime of these particles in the atmosphere, during which time, particle coagulation, gas condensation, and photochemistry would be expected to shift the aerosol population toward a more internally-mixed state. One explanation for this result is that the organic species are significantly less-soluble $(\kappa<0.11)$, or even insoluble, and that the aerosol mixing state is some combination of internally- and externally-mixed aerosol.

The PALMS data products show clearly that the fine mode aerosols are an external mixture of different particle types from different sources (Fig. 5 here and Fig. 7 in Brock et al. (2011)), while examination of single particle spectra show that most particles are internally mixed with both secondary sulfate and organic species. Thus, the internal and external 

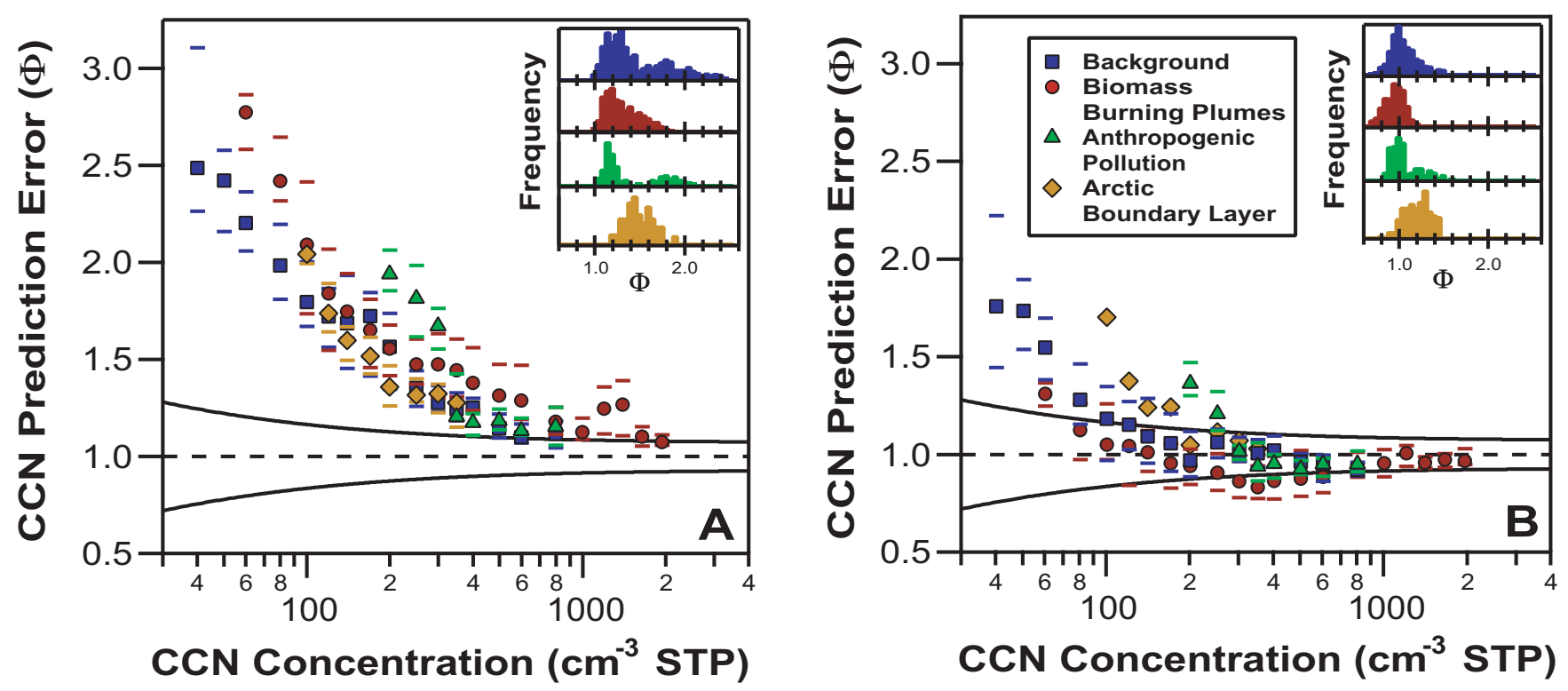

Fig. 10. $\mathrm{CCN}$ prediction error for $0.1-0.3 \%$ supersaturation versus measured $\mathrm{CCN}$ concentrations. Predictions were computed assuming that the aerosol is (a) internally-mixed, or (b) externally-mixed. Organic species are assumed to be soluble with $\kappa=0.11$. Markers denote the median error for each air mass type, and bars denote the interquartile range. The dotted line at $\Phi=1$ denotes perfect agreement and the solid bounding curves denote the CCN measurement uncertainty. The inset shows the frequency distribution of $\Phi$ for all $0.1 \mathrm{~Hz}$ data points.

mixture cases explored here bound reality and constrain the $\mathrm{CCN}$ activity of the real aerosol population. As an intermediate case, a size-dependent mixing state scenario was examined, where particles greater than a specified threshold diameter are assumed to be internally mixed, while particles smaller than the threshold diameter are treated as externally mixed. Organic species present across the entire size distribution are treated as slightly soluble as before. During ARCPAC, the C-ToF-AMS mass spectra signal-to-noise ratio was very low for particle diameters below $150-200 \mathrm{~nm}$, and so we use $200 \mathrm{~nm}$ as the threshold diameter in this scenario. The average overprediction assuming a size-dependent mixing state is shown in Table 1. Comparing this closure scenario to the internal mixture and external mixture cases with soluble organics shows the overprediction to be the same as the externally-mixed case at $0.2-0.3 \%$ supersaturations. Meanwhile the closure overprediction for $s=(0.1 \pm 0.04) \%$ falls between the two bounding cases. This is consistent with the peak sensitivity uncovered in Sect. 3.5, and provides a closure prediction estimate that is more consistent with the PALMS observations.

FLEXPART modeling of the transport of the biomass burning and anthropogenic pollution plumes indicates an Asian source with transport times of 4-9 days, while the background and Arctic boundary layer air mass types may reside in the Arctic atmosphere for a longer time (Brock et al., 2011; Fisher et al., 2010; Warneke et al., 2009). We speculate, then, that the biomass burning and anthropogenic plumes undergo aging and mixing processes during transport that result in an internally-mixed, well-oxidizedorganic-dominated aerosol type that is injected into the stratified Arctic atmosphere, where further mixing processes are somewhat suppressed. Meanwhile, the background and Arctic boundary layer air mass types are dominated by an existing population of predominantly-inorganic aerosol. The fact that PALMS shows a significant biomass burning signature for all air mass types indicates that mixing of air types is not completely suppressed, however, and aging processes blur the distinction between different particle types.

$\mathrm{CCN}$ prediction error was also found to vary with number concentration, as shown in Figs. 10a and b for the internallymixed and externally-mixed cases, respectively (and assuming soluble organics). The median overprediction increases for both cases as CCN concentration decreases, which cannot be fully-explained by the increase in measurement uncertainty associated with decreased CCN counting statistics (solid curves in Fig. 10). Higher AMS composition uncertainties at low particle concentrations may also contribute somewhat to this uncertainty. Additionally, analysis of PALMS spectra obtained during periods of low $\mathrm{CCN}$ concentration $\left(<70 \mathrm{~cm}^{-3}\right)$ in the background air masses suggests a relatively larger role of mineral dust with less soluble material than present at higher $\mathrm{CCN}$ concentrations. This would not be reflected in the closure calculation and may also explain the increased overprediction. $\mathrm{CCN}$ concentrations below $100 \mathrm{~cm}^{-3}$ were somewhat infrequent during ARCPAC and had little influence on the overall predictions reported in Table 1 , as reflected by the low occurrence of large $\Phi$ values 
in the inset frequency plots in Fig. 10. However, the range of $0-300 \mathrm{CCN} \mathrm{cm}^{-3}$ for springtime Arctic aerosol reported by previous studies suggests that the $\mathrm{CCN}$ prediction uncertainties associated with more pristine conditions occurring in the absence of strong biomass burning conditions may be even greater. Given the susceptibility of Arctic stratus to composition effects, such errors become important under low CCN concentrations

\section{Summary and conclusions}

Measurements of $\mathrm{CCN}$ and aerosol properties obtained during the ARCPAC project in April, 2008, are presented and analyzed. We find that size effects dominate the CCN activity because of the accumulation mode size distribution, and that most particles act as $\mathrm{CCN}$ above $0.1 \%$ supersaturation. However, we also find that aerosol chemistry and mixing state have important secondary effects, particularly in the prediction of $\mathrm{CCN}$ number concentration, which is shown to be sensitive to compositional assumptions near $0.1 \%$ supersaturation. Assuming the aerosol to be internally-mixed significantly overpredicts $\mathrm{CCN}$ concentration, and the best closure (0-20\% overprediction error) is obtained assuming an externally-mixed aerosol with soluble organics. Closure worsens for low $\mathrm{CCN}$ concentrations $\left(<100 \mathrm{~cm}^{-3}\right)$, where $\mathrm{CCN}$ are overpredicted by a factor of $1.5-3$. While these low concentration periods were infrequent during ARCPAC, and thus do not substantially affect the overall closure, past studies have frequently reported CCN concentrations in this range. Consequently, CCN prediction errors might be expected to be even greater for those conditions.

While this study indicates that aerosol mixing state plays a significant role in determining $\mathrm{CCN}$ activity, many current models treat aerosols solely as internal mixtures for computational efficiency. Consequently, we also quantify the $\mathrm{CCN}$ activity in terms of the size-dependent hygroscopicity parameter, $\kappa$, which was found to vary with supersaturation (and, hence, $D_{\mathrm{p}, \mathrm{c}}$ ) from 0.04 at the highest supersaturations $(s=0.4-0.6 \%)$ to $0.15-0.3$ at the lowest supersaturations $(s=0.1-0.3 \%)$. This observed size-dependence captures the size-dependent chemistry and mixing state effects not explicitly treated by the single-parameter model.

Strong biomass burning plumes originating in Asia and advected into the Arctic atmosphere during this study made this dataset particularly useful for examining a wide variety of Arctic pollution sources; however, mixing of the biomass emissions across air types means that extrapolating these results to more pristine springtime conditions without a significant biomass burning signature should be done with care. Recent work suggests, however, that biomass burning may be a larger contributor to Arctic haze than previously thought, and a warming climate will likely increase the prevalence of severe fire years in the future (Warneke et al., 2010; Stocks et al., 1998).
Acknowledgements. A. Nenes acknowledges support from NOAA, NASA, and an NSF CAREER award. R. Moore acknowledges support from DOE Global Change Education Program and NASA Earth and Space Science Graduate Research Fellowships. J. Cozic acknowledges support from the Swiss National Science Foundation under award PBBE22-119260. The ARCPAC project was supported by NOAA's Climate Change and Air Quality Programs.

Edited by: P. Quinn

\section{References}

Aiken, A. C., DeCarlo, P. F., Kroll, J. H., Worsnop, D. R., Huffman, J. A., Docherty, K. S., Ulbrich, I. M., Mohr, C., Kimmel, J. R., Sueper, D., Sun, Y., Zhang, Q., Trimborn, A., Northway, M., Ziemann, P. J., Canagaratna, M. R., Onasch, T. B., Alfarra, M. R., Prevot, A. S., Dommen, J., Duplissy, J., Metzger, A., Baltensperger, U., and Jimenez, J. L.: O/C and OM/OC ratios of primary, secondary, and ambient organic aerosols with highresolution time-of-flight aerosol mass spectrometry, Environ. Sci. Technol., 42, 4478-4485, doi:10.1021/es703009q, 2008.

Albrecht, B. A.: Aerosols, cloud microphysics, and fractional cloudiness, Science, 245, 1227-1230, doi:10.1126/science.245.4923.1227, 1989.

Allan, J. D., Jimenez, J. L., Williams, P. I., Alfarra, M. R., Bower, K. N., Jayne, J. T., Coe, H., and Worsnop, D. R.: Quantitative sampling using an Aerodyne aerosol mass spectrometer 1. Techniques of data interpretation and error analysis, J. Geophys. Res., 108, 4090, doi:10.1029/2002JD002358, 2003.

Alterskjær, K., Kristjánsson, J. E., and Hoose, C.: Do anthropogenic aerosols enhance or suppress the surface cloud forcing in the Arctic?, J. Geophys. Res., 115, D22204, doi:10.1029/2010JD014015, 2010.

Andreae, M. O. and Rosenfeld, D.: Aerosol-cloudprecipitation interactions. Part 1. The nature and sources of cloud-active aerosols, Earth-Sci. Rev., 89, 13-41, doi:10.1016/j.earscirev.2008.03.001, 2008.

Asa-Awuku, A., Engelhart, G., Lee, B., Pandis, S., and Nenes, A.: Relating CCN activity, volatility, and droplet growth kinetics of $\beta$-caryophyllene secondary organic aerosol, Atmos. Chem. Phys., 9, 795-812, doi:10.5194/acp-9-795-2009, 2009.

Asa-Awuku, A., Moore, R. H., Nenes, A., Bahreini, R., Holloway, J. S., Brock, C. A., Middlebrook, A. M., Ryerson, T. B., Jimenez, J. L., DeCarlo, P. F., Hecobian, A., Weber, R. J., Stickel, R., Tanner, D. J., and Huey, L. G.: Airborne cloud condensation nuclei measurements during the 2006 Texas Air Quality Study, J. Geophys. Res., 116, D11201, doi:10.1029/2010JD014874, 2011.

Bahreini, R., Dunlea, E. J., Matthew, B. M., Simons, C., Docherty, K. S., DeCarlo, P. F., Jimenez, J. L., Brock, C. A., and Middlebrook, A. M.: Design and operation of a pressure-controlled inlet for airborne sampling with an aerodynamic aerosol lens, Aerosol Sci. Technol., 42, 465-471, doi:10.1080/02786820802178514, 2008.

Bahreini, R., Ervens, B., Middlebrook, A. M., Warneke, C., de Gouw, J. A., DeCarlo, P. F., Jimenez, J. L., Brock, C. A., Neuman, J. A., Ryerson, T. B., Stark, H., Atlas, E., Brioude, J., Fried, A., Holloway, J. S., Peischl, J., Richter, D., Walega, J., Weibring, P., Wollny, A. G., and Fehsenfeld, F. C.: Organic aerosol formation in urban and industrial plumes near 
Houston and Dallas, Texas, J. Geophys. Res., 114, D00F16, doi:10.1029/2008JD011493, 2009.

Bigg, E. K. and Leck, C.: Cloud-active particles over the central Arctic Ocean, J. Geophys. Res., 106, 32155-32166, doi:10.1029/1999JD901152, 2001.

Borys, R. D., Lowenthal, D. H., and Mitchell, D. L.: The relationships among cloud microphysics, chemistry, and precipitation rate in cold mountain clouds, Atmos. Environ., 34, 2593-2602, doi:10.1016/S1352-2310(99)00492-6, 2000.

Borys, R. D., Lowenthal, D. H., Cohn, S. A., and Brown, W. O. J.: Mountaintop and radar measurements of anthropogenic aerosol effects on snow growth and snowfall rate, Geophys. Res. Lett., 30, 1538, doi:10.1029/2002GL016855, 2003.

Bougiatioti, A., Fountoukis, C., Kalivitis, N., Pandis, S. N., Nenes, A., and Mihalopoulos, N.: Cloud condensation nuclei measurements in the marine boundary layer of the eastern Mediterranean: CCN closure and droplet growth kinetics, Atmos. Chem. Phys., 9, 7053-7066, doi:10.5194/acp-9-7053-2009, 2009.

Brock, C. A., Schröder, F., Kärcher, B., Petzold, A., Busen, R., and Fiebig, M.: Ultrafine particle size distributions measured in aircraft exhaust plumes, J. Geophys. Res., 105, 26555-26567, doi:10.1029/2000JD900360, 2000.

Brock, C. A., Cozic, J., Bahreini, R., Froyd, K. D., Middlebrook, A. M., McComiskey, A., Brioude, J., Cooper, O. R., Stohl, A., Aikin, K. C., de Gouw, J. A., Fahey, D. W., Ferrare, R. A., Gao, R.-S., Gore, W., Holloway, J., Hübler, G., Jefferson, A., Lack, D. A., Lance, S., Moore, R. H., Murphy, D. M., Nenes, A., Novelli, P. C., Nowak, J. B., Ogren, J. A., Peischl, J., Pierce, R. B., Pilewskie, P., Quinn, P. K., Ryerson, T. B., Schmidt, K. S., Schwarz, J. P., Sodemann, H., Spackman, J. R., Stark, H., Thomson, D. S., Thornberry, T., Veres, P., Watts, L. A., Warneke, C., and Wollny, A. G.: Characteristics, sources, and transport of aerosols measured in Spring 2008 during the Aerosol, Radiation, and Cloud Processes Affecting Arctic Climate (ARCPAC) project, Atmos. Chem. Phys., 11, 2423-2453, doi:10.5194/acp11-2423-2011, 2011.

Broekhuizen, K., Chang, R. Y.-W., Leaitch, W. R., Li, S.-M., and Abbatt, J. P. D.: Closure between measured and modeled cloud condensation nuclei (CCN) using size-resolved aerosol compositions in downtown Toronto, Atmos. Chem. Phys., 6, 2513-2524, doi:10.5194/acp-6-2513-2006, 2006.

Chang, R. Y.-W., Slowik, J. G., Shantz, N. C., Vlasenko, A., Liggio, J., Sjostedt, S. J., Leaitch, W. R., and Abbatt, J. P. D.: The hygroscopicity parameter $(\kappa)$ of ambient organic aerosol at a field site subject to biogenic and anthropogenic influences: relationship to degree of aerosol oxidation, Atmos. Chem. Phys., 10, 50475064, doi:10.5194/acp-10-5047-201, 2010

Clegg, S. L. and Brimblecombe, P.: Equilibrium partial pressures of strong acids over concentrated saline solutions - I. $\mathrm{HNO}_{3}$, Atmos. Environ., 22, 91-100, doi:10.1016/0004-6981(88)90302-2, 1988.

Covert, D. S. and Heintzenberg, J.: Size distributions and chemical properties of aerosol at Ny Ålesund, Svalbard, Atmos. Environ., 27A, 2989-2997, doi:10.1016/0960-1686(93)90331-R, 1993.

DeCarlo, P. F., Kimmel, J. R., Trimborn, A., Northway, M. J., Jayne, J. T., Aiken, A. C., Gonin, M., Fuhrer, K., Horvath, T., Docherty, K. S., Worsnop, D. R., and Jimenez, J. L.: Field-deployable, high-resolution, time-of-flight aerosol mass spectrometer, Anal. Chem., 78, 8281-8289, doi:10.1021/ac061249n, 2006.
Decesari, S., Facchini, M. C., Mircea, M., Cavalli, F., and Fuzzi, S.: Solubility properties of surfactants in atmospheric aerosol and cloud/fog water samples, J. Geophys. Res., 108, 4685, doi:10.1029/2003JD003566, 2003.

Drewnick, F., Hings, S. S., DeCarlo, P., Jayne, J. T., Gonin, M., Fuhrer, K., Weimer, S., Jimenez, J. L., Demerjian, K. L., Borrmann, S., and Worsnop, D. R.: A new time-of-flight aerosol mass spectrometer (TOF-AMS) - Instrument description and first field deployment, Aerosol Sci. Technol., 39, 637-658, doi:10.1080/02786820500182040, 2005.

Duplissy, J., DeCarlo, P. F., Dommen, J., Alfarra, M. R., Metzger, A., Barmpadimos, I., Prévôt, A. S. H., Weingartner, E., Tritscher, T., Gysel, M., Aiken, A. C., Jimenez, J. L., Canagaratna, M. R., Worsnop, D. R., Collins, D. R., Tomlinson, J., and Baltensperger, U.: Relating hygroscopicity and composition of organic aerosol particulate matter, Atmos. Chem. Phys., 11, 1155-1165, doi:10.5194/acp-11-1155-2011, 2011.

Dusek, U., Frank, G. P., Hildebrandt, L., Curtius, J., Schneider, J., Walter, S., Chand, D., Drewnick, F., Hings, S., Jung, D., Borrmann, S., and Andreae, M. O.: Size matters more than chemistry for cloud-nucleating ability of aerosol particles, Science, 312, 1375-1378, doi:10.1126/science.1125261, 2006.

Engvall, A.-C., Krejci, R., Ström, J., Minikin, A., Treffeisen, R., Stohl, A., and Herber, A.: In-situ airborne observations of the microphysical properties of the Arctic tropospheric aerosol during late spring and summer, Tellus B, 60B, 392-404, doi:10.1111/j.1600-0889.2008.00348.x, 2008.

Ervens, B., Feingold, G., Frost, G. J., and Kreidenweis, S. M.: A modeling study of aqueous production of dicarboxylic acids: 1 . Chemical pathways and speciated organic mass production, J. Geophys. Res., 109, D15205, doi:10.1029/2003JD004387, 2004.

Facchini, M. C., Mircea, M., Fuzzi, S., and Charlson, R. J.: Cloud albedo enhancement by surface-active organic solutes in growing droplets, Nature, 401, 257-259, doi:10.1038/45758, 1999.

Fisher, J. A., Jacob, D. J., Purdy, M. T., Kopacz, M., Sager, P. L., Carouge, C., Holmes, C. D., Yantosca, R. M., Batchelor, R. L., Strong, K., Diskin, G. S., Fuelberg, H. E., Holloway, J. S., Hyer, E. J., McMillan, W. W., Warner, J., Streets, D. G., Zhang, Q., Wang, Y., and Wu, S.: Source attribution and interannual variability of Arctic pollution in spring constrained by aircraft (ARCTAS, ARCPAC) and satellite (AIRS) observations of carbon monoxide, Atmos. Chem. Phys., 10, 977-996, doi:10.5194/acp10-977-2010, 2010.

Garrett, T. J. and Zhao, C.: Increased arctic cloud longwave emissivity associated with pollution from mid-latitudes, Nature, 440, 787-789, doi:10.1038/nature04636, 2006.

Garrett, T. J., Radke, L. F., and Hobbs, P. V.: Aerosol effects on cloud emissivity and surface longwave heating in the Arctic, J. Atmos. Sci., 59, 769-778, doi:10.1175/15200469(2002)059<0769:AEOCEA > 2.0.CO;2, 2002.

Hegg, D. A., Ferek, R. J., and Hobbs, P. V.: Cloud condensation nuclei over the Arctic Ocean in early Spring, Journal of Applied Meteorology, 34, 2076-2082, doi:10.1175/15200450(1995)034<2076:CCNOTA > 2.0.CO;2, 1995.

Hegg, D. A., Hobbs, P. V., Gassó, S., Nance, J. D., and Rangno, A. L.: Aerosol measurements in the Arctic relevant to direct and indirect radiative forcing, J. Geophys. Res., 101, 23349-23363, doi:10.1029/96JD02246, 1996.

Heintzenberg, J.: Particle size distribution and optical proper- 
ties of Arctic haze, Tellus, 32, 251-260, doi:10.1111/j.21533490.1980.tb00952.x, 1980.

Heintzenberg, J., Leck, C., Birmili, W., Wehner, B., Tjernström, M., and Wiedensohler, A.: Aerosol number-size distributions during clear and fog periods in the summer high Arctic: 1991, 1996, and 2001, Tellus B, 58, 41-50, doi:10.1111/j.16000889.2005.00171.x, 2006.

Herich, H., Kammermann, L., Friedman, B., Gross, D. S., Weingartner, E., Lohmann, U., Spichtinger, P., Gysel, M., Baltensperger, U., and Cziczo, D. J.: Subarctic atmospheric aerosol composition: 2. Hygroscopic growth properties, J. Geophys. Res., 114, D13204, doi:10.1029/2008JD011574, 2009.

Hoppel, W. A., Dinger, J. E., and Ruskin, R. E.: Vertical profiles of $\mathrm{CCN}$ at various geographical locations, Journal of the Amospheric Sciences, 30, 1410-1420, doi:10.1175/15200469(1973)030<1410:VPOCAV>2.0.CO;2, 1973.

Ji, Q., Shaw, G. E., and Cantrell, W.: A new instrument for measuring cloud condensation nuclei: Cloud condensation nucleus "remover", J. Geophys. Res., 103, 28,013-28,019, doi:10.1029/98JD01884, 1998.

Jimenez, J., Canagaratna, M. R., Donahue, N. M., Prevot, A. S. H., Zhang, Q., Kroll, J. H., DeCarlo, P. F., Allan, J. D., Coe, H., Ng, N. L., Aiken, A. C., Docherty, K. S., Ulbrich, I. M., Grieshop, A. P., Robinson, A. L., Duplissy, J., Smith, J. D., Wilson, K. R., Lanz, V. A., Hueglin, C., Sun, Y. L., Tian, J., Laaksonen, A., Raatikainen, T., Rautiainen, J., Vaattovaara, P., Ehn, M., Kulmala, M., Tomlinson, J. M., Collins, D. R., Cubison, M. J., Dunlea, E. J., Huffman, A., Onasch, T. B., Alfarra, M. R., Williams, P. I., Bower, K., Kondo, Y., Schneider, J., Drewnick, F., Borrmann, S., Weimer, S., Demerjian, K., Salcedo, D., Cottrell, L., Griffin, R., Takami, A., Miyoshi, T., Hatakeyama, S., Shimono, A., Sun, J. Y., Zhang, Y. M., Dzepina, K., Kimmel, J. R., Sueper, D., Jayne, J. T., Herndon, S. C., Trimborn, A. M., Williams, L. R., Wood, E. C., Middlebrook, A. M., Kolb, C. E., Baltensperger, U., and Worsnop, D. R.: Evolution of organic aerosols in the atmosphere, Science, 326, 1525-1529, doi:10.1126/science.1180353, 2009.

Kammermann, L., Gysel, M., Weingartner, E., Herich, H., Cziczo, D. J., Holst, T., Svenningsson, B., Ameth, A., and Baltensperger, U.: Subarctic atmospheric aerosol composition: 3. Measured and modeled properties of cloud condensation nuclei, J. Geophys. Res., 115, D04202, doi:10.1029/2009JD012447, 2010.

King, S. M., Rosenoern, T., Shilling, J. E., Chen, Q., and Martin, S. T.: Cloud condensation nucleus activity of secondary organic aerosol particles mixed with sulfate, Nucl. Atmos. Aerosols, 10, 1200-1204, doi:10.1007/978-1-4020-6475-3_238, 2007.

Köhler, H.: The nucleus in and growth of hygroscopic droplets, Trans. Faraday Soc., 32, 1152-1161, doi:10.1039/TF9363201152, 1936.

Korhonen, H., Carslaw, K. S., Spracklen, D. V., Ridley, D. A., and Ström, J.: A global model study of processes controlling aerosol size distributions in the Arctic spring and summer, J. Geophys. Res., 113, D08211, doi:10.1029/2007JD009114, 2008.

Lance, S., Medina, J., Smith, J. N., and Nenes, A.: Mapping the operation of the DMT continuous-flow CCN counter, Aerosol Sci. Technol., 40, 242-254, doi:10.1080/02786820500543290, 2006.

Lance, S., Shupe, M. D., Feingold, G., Brock, C. A., Cozic, J., Holloway, J. S., Moore, R. H., Nenes, A., Schwarz, J. P., Spack- man, J. R., Froyd, K. D., Murphy, D. M., Brioude, J., Cooper, O. R., Stohl, A., and Burkhart, J. F.: Cloud condensation nuclei as a modulator of ice processes in Arctic mixed-phase clouds, Atmos. Chem. Phys., 11, 8003-8015, doi:10.5194/acp-11-80032011, 2011.

Law, K. S. and Stohl, A.: Arctic air pollution: Origins and impacts, Science, 315, 1537-1540, doi:10.1126/science.1137695, 2007.

Leck, C., Norman, M., Bigg, E. K., and Hillamo, R.: Chemical composition and sources of the high Arctic aerosol relevant for cloud formation, J. Geophys. Res., 107, 4135, doi:10.1029/2001JD001463, 2002.

Lim, Y. B., Tan, Y., Perri, M. J., Seitzinger, S. P., and Turpin, B. J.: Aqueous chemistry and its role in secondary organic aerosol (SOA) formation, Atmos. Chem. Phys., 10, 1052110539, doi:10.5194/acp-10-10521-201, 2010.

Lohmann, U. and Leck, C.: Importance of submicron surface-active organic aerosols for pristine Arctic clouds, Tellus B, 57B, 261268, doi:10.1111/j.1600-0889.2005.00144.x, 2005.

Lubin, D. and Vogelmann, A. M.: A climatologically significant aerosol longwave indirect effect in the Arctic, Nature, 439, 453456, doi:10.1038/nature04449, 2006.

Mauritsen, T., Sedlar, J., Tjernström, M., Leck, C., Martin, M., Shupe, M., Sjogren, S., Sierau, B., Persson, P. O. G., Brooks, I. M., and Swietlicki, E.: An Arctic CCN-limited cloud-aerosol regime, Atmos. Chem. Phys., 11, 165-173, doi:10.5194/acp-11165-2011, 2011.

Medina, J., Nenes, A., Sotirpoulou, R.-E. P., Cottrell, L. D. Ziemba, L. D., Beckman, P. J., and Griffin, R. J.: Cloud condensation nuclei closure during the International Consortium for Atmospheric Research on Transport and Transformation 2004 campaign: Effects of size-resolved composition, J. Geophys. Res., 112, D10S31, doi:10.1029/2006JD007588, 2007.

Middlebrook, A. M., Bahreini, R., Jimenez, J. L., and Canagaratna, M. R.: Evaluation of composition-dependent collection efficiencies for the Aerodyne aerosol mass spectrometer using field data, Aerosol Sci. Technol., 46, 258-271, doi:10.1080/02786826.2011.620041, 2012.

Moore, R. H., Nenes, A., and Medina, J.: Scanning mobility CCN analysis - A method for fast measurements of size-resolved CCN distributions and activation kinetics, Aerosol Sci. Technol., 44, 861-871, doi:10.1080/02786826.2010.498715, 2010.

Murphy, D. M., Cziczo, D. J., Froyd, K. D., Hudson, P. K., Matthew, B. M., Middlebrook, A. M., Peltier, R. E., Sullivan, A., Thomson, D. S., and Weber, R. J.: Single-particle mass spectrometry of tropospheric aerosol particles, J. Geophys. Res., 111, D23S32, doi:10.1029/2006JD007340, 2006.

Myriokefalitakis, S., Tsigaridis, K., Mihalopoulos, N., Sciare, J., Nenes, A., Kawamura, K., Segers, A., and Kanakidou, M.: In-cloud oxalate formation in the global troposphere: a 3-D modeling study, Atmos. Chem. Phys., 11, 5761-5782, doi:10.5194/acp-11-5761-2011, 2011.

Nenes, A., Pandis, S. N., and Pilinis, C.: ISORROPIA: A new thermodynamic equilibrium model for multiphase multicomponent aerosols, Aquat. Geochem., 4, 123-152, doi:10.1023/A:1009604003981, 1998.

Ng, N. L., Canagaratna, M. R., Zhang, Q., Jimenez, J. L., Tian, J., Ulbrich, I. M., Kroll, J. H., Docherty, K. S., Chhabra, P. S., Bahreini, R., Murphy, S. M., Seinfeld, J. H., Hildebrandt, L., Donahue, N. M., DeCarlo, P. F., Lanz, V. A., Prévôt, A. S. H., 
Dinar, E., Rudich, Y., and Worsnop, D. R.: Organic aerosol components observed in Northern Hemispheric datasets from Aersosol Mass Spectrometry, Atmos. Chem. Phys., 10, 4625-4641, doi:10.5194/acp-10-4625-2010, 2010.

Petters, M. D. and Kreidenweis, S. M.: A single parameter representation of hygroscopic growth and cloud condensation nucleus activity, Atmos. Chem. Phys., 7, 1961-1971, doi:10.5194/acp-86273-2008, 2007.

Pitzer, K. S. and Mayorga, G.: Thermodynamics of electrolytes. II. Activity and osmotic coefficients for strong electrolytes with one or both ions univalent, J. Phys. Chem., 77, 2300-2308, doi:10.1021/j100638a009, 1973.

Quinn, P. K., Shaw, G., Andrews, E., Dutton, E. G., RuohoAirola, T., and Gong, S. L.: Arctic haze: current trends and knowledge gaps, Tellus B, 59B, 99-114, doi:10.1111/j.16000889.2006.00238.x, 2007.

Quinn, P. K., Bates, T. S., Baum, E., Doubleday, N., Fiore, A. M., Flanner, M., Fridlind, A., Garrett, T. J., Koch, D., Menon, S., Shindell, D., Stohl, A., and Warren, S. G.: Short-lived pollutants in the Arctic: their climatic impact and possible mitigation strategies, Atmos. Chem. Phys., 8, 1723-1735, doi:10.5194/acp8-1723-2008, 2008.

Rissler, J., Swietlicki, E., Zhou, J., Roberts, G., Andreae, M. O., Gatti, L. V., and Artaxo, P.: Physical properties of the submicrometer aerosol over the Amazon rain forest during the wetto-dry season transition - comparison of modeled and measured CCN concentrations, Atmos. Chem. Phys., 4, 2119-2143, doi:10.5194/acp-4-2119-2004, 2004.

Roberts, G. C. and Nenes, A.: A continuous-flow streamwise thermal-gradient $\mathrm{CCN}$ chamber for atmospheric measurements, Aerosol Sci. Technol., 39, 206-221, doi:10.1080/027868290913988, 2005.

Rose, D., Gunthe, S. S., Mikhailov, E., Frank, G. P., Dusek, U., Andreae, M. O., and Pöschl, U.: Calibration and measurement uncertainties of a continuous-flow cloud condensation nuclei counter (DMT-CCNC): CCN activation of ammonium sulfate and sodium chloride aerosol particles in theory and experiment, Atmos. Chem. Phys., 8, 1153-1179, doi:10.5194/acp-8-11532008, 2008.

Rose, D., Nowak, A., Achtert, P., Wiedensohler, A., Hu, M., Shao, M., Zhang, Y., Andreae, M. O., and Pöschl, U.: Cloud condensation nuclei in polluted air and biomass burning smoke near the mega-city Guangzhou, China - Part 1: Size-resolved measurements and implications for the modeling of aerosol particle hygroscopicity and CCN activity, Atmos. Chem. Phys., 10, 33653383, doi:10.5194/acp-10-3365-2010, 2010.

Shaw, G. E.: On the aerosol particle size distribution spectrum in Alaskan air mass systems: Arctic haze and non-haze episodes, J. Atmos. Sci., 40, 1313-1320, doi:10.1175/15200469(1983)040<1313:OTAPSD>2.0.CO;2, 1983.

Shaw, G. E.: Microparticle size spectrum of Arctic haze, Geophys. Res. Lett., 11, 409-412, doi:10.1029/GL011i005p00409, 1984.

Shaw, G. E.: Cloud condensation nuclei associated with Arctic haze, Atmos. Environ., 20, 1453-1456, doi:10.1016/00046981(86)90017-X, 1986.

Shaw, G. E.: The Arctic haze phenomenon, B. Am. Meteorol. Soc., 76, 2403-2413, doi:10.1175/15200477(1995)076<2403:TAHP>2.0.CO;2, 1995.

Shupe, Matthew, D. and Interieri, J. M.: Cloud radiative forcing of the Arctic surface: The influence of cloud properties, surface albedo, and solar zenith angle, J. Climate, 17, 616-628, doi:10.1175/1520-0442(2004)017<0616:CRFOTA > 2.0.CO;2, 2004.

Stocks, B. J., Fosberg, M. A., Lynham, T. J., Mearns, L., Wotton, B. M., Yang, Q., Jin, J.-Z., Lawrence, K., Hartley, G. R., Mason, J. A., and McKenney, D. W.: Climate change and forest fire potential in Russian and Canadian Boreal Forests, Clim. Change, 38, 1-13, doi:10.1023/A:1005306001055, 1998.

Stohl, A., Andrews, E., Burkhart, J. F., Forster, C., Herber, A., Hoch, S. W., Kowal, D., Lunder, C., Mefford, T., Ogren, J. A., Sharma, S., Spichtinger, N., Stebel, K., Stone, R., Ström, J., Tørseth, K., Wehrli, C., and Yttri, K. E.: Pan-Arctic enhancements of light absorbing aerosol concentrations due to North American boreal forest fires during summer 2004, J. Geophys. Res., 111, D22214, doi:10.1029/2006JD007216, 2006.

Stohl, A., Berg, T., Burkhart, J. F., Fjæraa, A. M., Forster, C., Herber, A., Hov, Ø., Lunder, C., McMillan, W. W., Oltmans, S., Shiobara, M., Simpson, D., Solberg, S., Stebel, K., Ström, J., Tørseth, K., Treffeisen, R., Virkkunen, K., and Yttri, K. E.: Arctic smoke - record high air pollution levels in the European Arctic due to agricultural files in Eastern Europe in spring 2006, Atmos. Chem. Phys., 7, 511-534, doi:10.5194/acp-7-511-2007, 2007.

Ström, J., Umegård, J., Tørseth, K., Tunved, P., Hansson, H.C., Holmén, K., Wismann, V., Herber, A., and König-Langlo, G.: One year of particle size distribution and aerosol chemical composition measurements at the Zeppelin Station, Svalbard, March 2000- March 2001, Phys. Chem. Earth, 28, 1181-1190, doi:10.1016/j.pce.2003.08.058, 2003.

Thomson, D. S., Schein, M. E., and Murphy, D. M.: Particle analysis by laser mass spectrometry WB-57F instrument overview, Aerosol Sci. Technol., 33, 153-169, doi:10.1080/027868200410903, 2000.

Twomey, S.: The influence of pollution on the shortwave albedo of clouds, J. Atmos. Sci., 34, 1149-1152, doi:10.1175/15200469(1977)034<1149:TIOPOT>2.0.CO;2, 1977a.

Twomey, S.: Atmospheric Aerosols, Developments in Atmospheric Science, Elsevier Sci., 1977b.

VanReken, T. M., Rissman, T. A., Roberts, G. C., Varutbangkul, V., Jonsson, H. H., Flagan, R. C., and Seinfeld, J. H.: Toward aerosol/cloud condensation nuclei $(\mathrm{CCN})$ closure during CRYSTAL-FACE, J. Geophys. Res., 108, 4633, doi:10.1029/2003JD003582, 2003.

Wang, J., Cubison, M. J., Aiken, A. C., Jimenez, J. L., and Collins, D. R.: The importance of aerosol mixing state and size-resolved composition on CCN concentration and the variation of the importance with atmospheric aging of aerosols, Atmos. Chem. Phys., 10, 7267-7283, doi:10.5194/acp-10-7267-2010, 2010.

Warneke, C., Bahreini, R., Brioude, J., Brock, C. A., de Gouw, J. A., Fahey, D. W., Froyd, K. D., Holloway, J. S., Middlebrook, A., Miller, L., Montzka, S., Murphy, D. M., Peischl, J., Ryerson, T. B., Schwarz, J. P., Spackman, J. R., and Veres, P.: Biomass burning in Siberia and Kazakhstan as an important source for haze over the Alaskan Arctic in April 2008, Geophys. Res. Lett., 36, L02813, doi:10.1029/2008GL036194, 2009.

Warneke, C., Froyd, K. D., Brioude, J., Bahreini, R., Brock, C. A., Cozic, J., de Gouw, J. A., Fahey, D. W., Ferrare, R., Holloway, J. S., Middlebrook, A. M., Miller, L., Montzka, S., Schwarz, J. P., 
Sodemann, H., and Spackman, J. R.: An important contribution to springtime Arctic aerosol from biomass burning in Russia, Geophys. Res. Lett., 37, L01801, doi:10.1029/2009GL041816, 2010.

Wylie, D. P. and Hudson, J. G.: Effects of long-range transport and clouds on cloud condensation nuclei in the springtime Arctic, J. Geophys. Res., 107, 4318, doi:10.1029/2001JD000759, 2002.

Yum, S. S. and Hudson, J. G.: Vertical distributions of cloud condensation nuclei spectra over the springtime Arctic Ocean, J. Geophys. Res., 106, 15045-15052, doi:10.1029/2000JD900357, 2001.
Zhang, Q., Alfarra, M. R., Worsnop, D. R., Allan, J. D., Coe, H., Canagaratna, M. R., and Jimenez, J. L.: Deconvolution and quantification of hydrocarbon-like and oxygenated organic aerosols based on aerosol mass spectrometry, Environ. Sci. Technol., 39, 4938-4952, doi:10.1021/es0485681, 2005.

Zhou, J., Swietlicki, E., Berg, O. H., Aalto, P. P., Hämeri, K., Nilsson, E. D., and Leck, C.: Hygroscopic properties of aerosol particles over the central Arctic Ocean during summer, J. Geophys. Res., 106, 32111-32123, doi:10.1029/2000JD900426, 2001. 